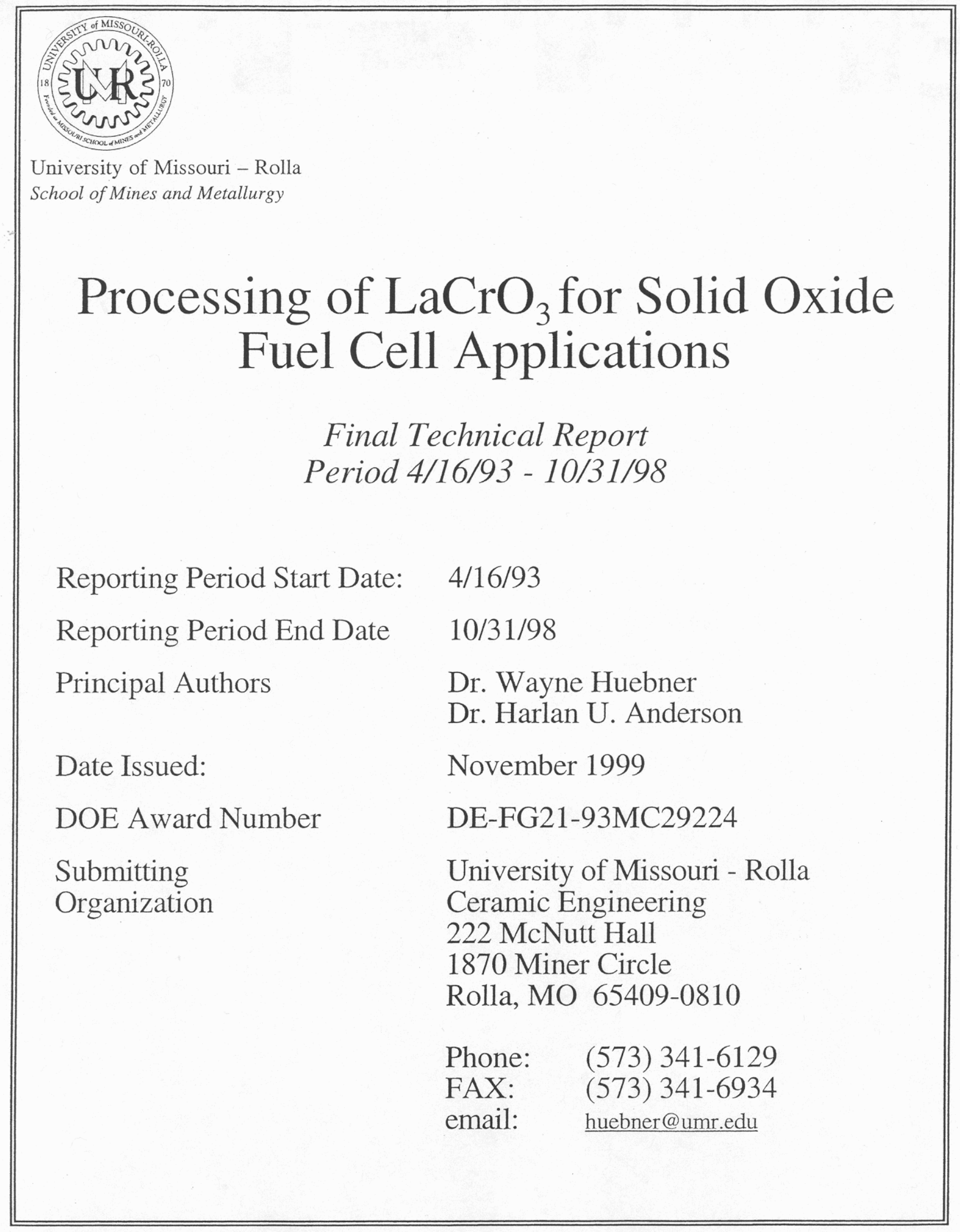




\section{DISCLATMER}

This report was prepared as an account of work sponsored by an agency of the United States Government. Neither the United States Government nor any agency thereof, nor any of their employees, makes any warranty, express or implied, or assumes any legal liability or responsibility for the accuracy, completeness, or usefulness of any information, apparatus, product, or process disclosed, or represents that its use would not infringe privately owned rights. Reference herein to any specific commercial product, process, or service by uade name, trademark, manufacturer, or otherwise does not necessarily constitute or imply-its endorsement, recommendation, or favoring by the United States Government or any agency thereof. The views and opinions of authors expressed herein do not necessarily state or reflect those of the United States Government or any agency thereof. 
ABSTRACT

In this portion of the research we are focusing on the microstructure $\Leftrightarrow$ property relations in solid oxide fuel cells (SOFC's) to better understand the mechanisms involved in cell performance. The overall am is to fabricate SOFC's with controlled microstructures utilizing $\mathrm{La}_{\mathrm{I}-\mathrm{x}} \mathrm{Sr}_{\mathrm{x}} \mathrm{MnO}_{3}$ (LSM), ytria stabilized zirconia (YSZ), and Ni-YSZ composites as the cathode, electrolyte, and anode, respectively. Ideally, the clectrode materials would be tailored for an increased reaction rate (grain size $\leq 1 \mu \mathrm{m})$, be stable with time $(>10,000 \mathrm{~h}$ ), have a thermal expansion match to $\mathrm{YSZ}$ $\left(a-11 \times 10^{-6 / 9} \mathrm{C}\right)$, show limited chemical interaction with the electrolyte, and show no degradation in electrical performance. This paper describes anodic studies, including starting powder characteristics, electrical conductivity and overpotential measurements, and resultant microstructures as a function of processing conditions (1.e. powder calcination temperature, and annesaling temperature) and composition.

Durng the last year several important discoveries have been made regarding the influence of composition and microstructure of anodes on the perfomance of otr SOFC's. These results can be summarized as follows:

- YSZ anodes prepared with lower Ni volume fractions $(40$ \& $45 \%$ ) resulted in lower overpotentials and improved stability.

- Higher sintering temperatures effectively lowered the overpotential and increased the in-plane conductivity. Due to constrained sintering between the anode and the YSZ electrolyte, higher sintering temperatures allowed more densification in the $\mathrm{z}$-direction, resulting in a rigid YSZ structure to support Ni particles

- By decreasing the densification between Ni grains, there are more paths for conduction (more Ni-Ni contacts throughout the structure and higher conductivities) and a larger number of NiYSZ contacts (lower overpotentials).

- The 45 vol\% Ni composition co-fired with the electrolyte had the lowest initial overpotential of any cermet with a similar composition. 


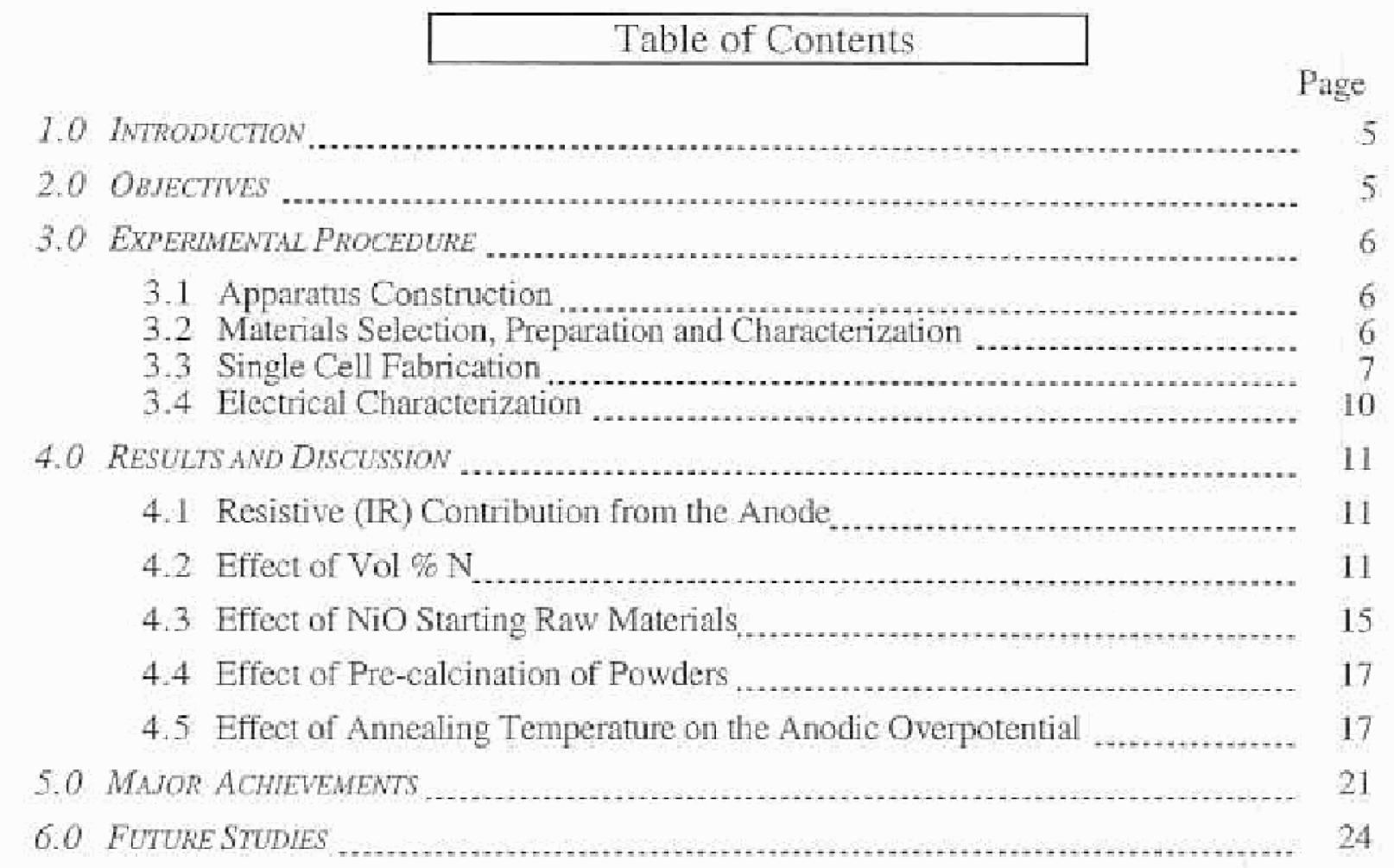




\title{
Solid Oxide Fuel Cell Performance Studies: Anode Development
}

\author{
Wayne Huebner (huebner@umredu; 573-341-6129) \\ Harlan U. Anderson (harlanua eumredu; 573-341-4886) \\ Department of Ceramic Enginesing \\ University of Missouri - Rolla \\ 222 McNutt Hall \\ Rolla, MO 65401
}

Contractor

Board of Curators

University of Missouri System

204 Parker Hall

Rolla, MO 65401

1.0 INTRODUCTION

Materials research focused on solid oxide fuel cells (SOFC) is driven by the recognition that processing and operating at lower temperatures would directly address many reliability problems. Hence numerous research groups around the globe are in pursuit of altemate materials for all four SOFC components with higher conductivities at lower temperatures, mixed-conducting cathodes, novel synthesis techniques (for powders and thin films), controlled and stable microstructures, and chemical, mechanical, and electrical stability under the temperature/time/atmosphere conditions of cofiring and operation.

In this portion of the research we are focusing on the microstructure $\leftrightarrow$ property relations in solid oxide fitel cells (SOFC'5) to better understand the mechanisms involved in cell performance. The overall aim is to fabricate SOFC's with controlled microstructures utilizing $\mathrm{L}_{1} \mathrm{~S}_{\mathrm{x}} \mathrm{Sr}_{\mathrm{x}} \mathrm{MnO}_{3}$ (LSM), yttria stabilized zirconia (YSZ), and Ni-YSZ composites as the cathode, electrolyte, and anode, respectively. Ideally, the electrode materials would be tailored for an increased reaction rate (grain size $\leq 1 \mu \mathrm{m}$ ), be stable with time $(>10,000 \mathrm{~h}$ ), have a thermal expansion match to YSZ $\left(\alpha-11 \times 10^{-6 /} \mathrm{C}\right)$, show limited chemical interaction with the electrolyte, and show no degradation in electrical performance. This paper describes anodic studies, including starting powder characteristics, electrical conductivity and overpotential measurements, and resultant microstructures as a function of processing conditions (1.e. powder calcination temperature, and annealing temperature) and composition.

\subsection{OBJECTIVES}

The University of Missouri-Rolla is in the last year of a 5 year research program with two primary objectives: 1) developing $\mathrm{LaCrO}_{3}$-based interconnect powders which densify when in contact with anode and cathode materials for solid oxide fuel cells (SOFC), and 2) developing high perfomance cathodes, anodes and interfaces for use in planar SOFC's. The latter is the focus of this paper. With regard to developing high performance materials for use in planar SOFC's, the specific objectives of this research program over the last year have been to develop processing $t$ ? microstructure $\leftrightarrow$ property relations of the anode and its corresponding interfacial reactions. 


\subsection{Experimental Procedure}

\subsection{Apparatus Construction}

The system constructed for measuring cell performance is a Kanthal-heated, three-zone, halfshell furnace $\left(1100^{\circ} \mathrm{C}\right)$. The self supporting electrolyte is mounted and sealed to two nullite tubes using a ceramic adhesive/sealant, Aremco 503. This sealant is an alumina-based cement with a working temperature up to $1650^{\circ} \mathrm{C}$. For all studies, planar SOFC's were heated at $-2^{\circ} \mathrm{Cm}$ min and held at $1000^{\circ} \mathrm{C}$ until all characterization was completed. Samples could not be thermally cycled due to the difference in themal expansion, 7.5 and $10.5 \mathrm{ppm} /{ }^{2} \mathrm{C}$ for the cement and YSZ electrolyte, tespectively. Both mullite tubes were sealed to the ends of an outer silica tube of $63.5 \mathrm{~mm}\left(21 / 2^{*}\right)$ OD by use of aluminum faceplates, silicone O-rings, and a Vacoa seal. Gas inlet and outlet ports were drilled into the aluminum faceplates and sealed using Swagelock connectors. The outer end of the mullite tubes were also sealed using stainless steel faceplates and silicone $\mathrm{O}$-rings. $\mathrm{Pt}$ and $\mathrm{Ni}$ wires for cathode and anode sensing, respectively, were inserted into the alumina tubes to make electrical connection to the YSZ electrolyte. Baffles made of sali board were placed insido the mullite tubes to help mixing of the gases and also acted as positioners for the alumina thermocouple tubes to ensure proper electrical connection.

Both oxidant and fuel flow rates were controlled using Tylan Model FC-260 mass flow controllers. Air was used as the oxidant in the majority of experiments, with a flow rate of 200 sccm. Pure oxygen was also used in some experiments and was delivered at a rate of 200 secm. A mixture of forming gas, $\left.\mathrm{FG}_{3}, 90 \% \mathrm{~N}_{2}-10 \% \mathrm{H}_{2}\right)$ and $\mathrm{CO}_{2}$ was used as the fucl and had comesponding flow rates of 200 and $2 \mathrm{sccm}$, respectively. The FG-CO2 mixture gave Nemst potentials of 1.00 and $1.05 \mathrm{~V}$ with air and $\mathrm{O}_{2}$, respectively. The $\mathrm{FG}-\mathrm{CO}_{2}$ mixture had a $\mathrm{pO}_{2}$ cqual to $10^{-16.5}$ at $1000^{\circ} \mathrm{C}$. Nitrogen was delivered into the silica to sweep away any oxidant or fuel leaking out of the active region of the cell. In all experiments air was introduced in the top tube; fuel to the bottom tube, and the sweep gas was fed to the bottom and exited the top.

\subsection{Materials Selection, Preparation and Characterization}

The purpose of this inwestigation was to study the influence of microstructure and composition on the performance of anodes in single SOFCs. Commercially available Y stabilized $\mathrm{ZNO}_{2}$ (YSZ) powders were used in this study for the electrolyte and as a major constituent in the anode. Anode $\left[\mathrm{YSZ}-\mathrm{Ni}{ }_{1, \mathrm{M}} \mathrm{Mg} \mathrm{O}(\mathrm{x}=0.0,0.1)\right]$, compositions were synthesized by the glycine nitrate method.

The commerciatly-available $\mathrm{Y}$-doped $\mathrm{ZrO}_{2}$ (Zirconia Sales of America Inc) is a fully stabilized ( 8 mole $\% \mathrm{Y}_{2} \mathrm{O}_{3}$ ), co-precipitated powder. This particular powder was chosen because of its low cost, $-\$ 70 / \mathrm{kg}$, low impurity content and low densification temperature, $-1400^{\circ} \mathrm{C}$. The YSZ powder had a primary particle size of approximately $250 \mathrm{~nm}$ and a corresponding BET surface area of $-8.0 \mathrm{~m}^{2} / \mathrm{g}$.

$\mathrm{NiO}$, and $\mathrm{Mg}$-doped $\mathrm{NiO}$ were synthesized using the glycine nitrate method with $\mathrm{Ni}\left(\mathrm{NO}_{3}\right)_{2} \cdot \mathrm{xH}_{2} \mathrm{O}, \mathrm{MgCO}_{3}$ glycine, and distilled water as the starting naterals. The starting raw materials were thermogravimetrically sandardized to determine the cation concentration. Gentle heating $\left(>100^{\circ} \mathrm{C}\right.$ ) resulted in the evaporation of excess water, yielding a viscous liquid. Further heating cause the precursor solution to ignite and resulted in the formation of a fine powder. The powder was then calcined in $\mathrm{MgO}$ crucibles at temperatures ranging from $700^{\circ} \mathrm{C}-1000^{\circ} \mathrm{C}$ for $4 \mathrm{~h}$. 
The resultant powder was vibratory milled dry for $4 \mathrm{~h}$ with $\mathrm{ZrO}_{2}$ media. Powder crystallinity, phase, and surface area were characterized using $X$-ray diffraction and BET techniques as a function of calcination temperature.

A YSZ-NiO (45 vol \% Ni) composition was also prepared in which both components were combusted simultaneously using the glycine ritrate process. Starting raw materials were $\left.\mathrm{Ni}_{2} \mathrm{NO}_{3}\right)_{2} \times \mathrm{H}_{2} \mathrm{O}, \mathrm{Y}\left(\mathrm{NO}_{3}\right)_{3} \times \mathrm{H}_{2} 0$, and a zirconium citrate complex Resultant powders were calcined and milled and the crystallinity and phase were characterized using $\mathrm{X}$-ray diffraction as a function of calcination temperature.

A total of three different techniques were used to prepare powder mixtures with the goal of producing different resultant microstructures including: 1) mixing YSZ with $\mathrm{Ni}_{1-\mathrm{x}} \mathrm{Mg} \mathrm{g}_{\mathrm{O}} \mathrm{O}(\mathrm{x}=0.0$, $0.1,0.2)$ 2) mixing YSZ with NiO followed by calcination at $1400^{\circ} \mathrm{C}$ for 4 h and 3) simultaneous combustion of both components using the glycine titrate technique.

\subsection{Single Cell Fabrication}

The YSZ electrolyte used in this investigation was self supporting ( $~ 200 \mu \mathrm{m}$ thick) and the cathode and anode were applied via screen primting onto a pre-sintered dense electrolyte. A flowehart deseribing the techniques used to fabricate single cells is shown in Figure 1.

\section{Electrolyte fabrication}

YSZ powders were initially dried at $150^{\circ} \mathrm{C}$ to remove any physically bonded water and then mixed with a commercially awailable binder systen from Ferro Corp, B73210. This pre-mixed solution contains binder, plasticizer, solvents, and dispersants with a solids content of 18 wto. The binder, and solvents ane polywinyl butyral, and ethanol and toluene, respectively. The proportion of YSZ to B73210 by weight was approximately 50/50. A glass release agent, M1111, and a surfactant, M1135, were added to the slip to facilitate removal of the dried tape from the glass and to improve the dispersion behavior of the YSZ powder, respectively. The glass release agent and surfactant were added at a ratio of 1 and 2 wt \% of the total organic content, B73210. The slip was ball milled with $\mathrm{ZrO}_{2}$ media for 24 - $48 \mathrm{~h}$ until the powder was well dispersed. The theological behavior of the YSZ slip was measured using a HAAKE Viscotester Model VT 500.

The slurry was tape cast using the doctor blade technique at a take-off height of -250 um and the resultant dried tapes were $-50-75 \mu \mathrm{m}$. The tape was dried for at least $24 \mathrm{~h}$ prior to use to ensure removal of all wolatile species. The final proportion of powder to binder (total vol \% solids in the tape) was approximately 50/50. Dried tapes were inspected with a light table to discard any defective regions. Circular samples of 2 inch diameter were cut out of the tape and a Pt voltage probe (38 mm long $\times 0.3 \mathrm{~mm}$ wide) was screen printed onto the XSZ tape. The Pt, E1170 (Fenro Corp.), is a fritless, screen-printable paste with a solids content of $70 \mathrm{wt} \%$. A stainless steel 325 mesh screen with an emulsion thickness of 0.1 mil was used. The Pt probe was screen printed to the edge of the YSZ tape for electrical connection. The tape was again dried for at least $24 \mathrm{~h}$ prior to use to ensure removal of all volatile species from the Pt paste.

The tapes (six total) were stacked and laminated at 3000 psi for $10 \mathrm{~min}$ at $70^{\circ} \mathrm{C}$ in such a way. as to place the Pt probe in the center of the fired specimen, Figure 2. The themal processing schedule for binder removal and densification of the YSZ laminates was $0.5^{\circ} \mathrm{C} /$ min to $350^{\circ} \mathrm{C}$, hold for $1 \mathrm{~h}, 3^{\circ} \mathrm{C} / \mathrm{min}$ up to $1450^{\circ} \mathrm{C}$, hold for $2 \mathrm{~h}$, and then cool at $3^{\circ} \mathrm{C} / \mathrm{min}$. Sintered YSZ dimensions were $3.2 \mathrm{~cm}$ and $200 \mu \mathrm{m}$ for the diameter and thickness, respectively. The sintered specimen 


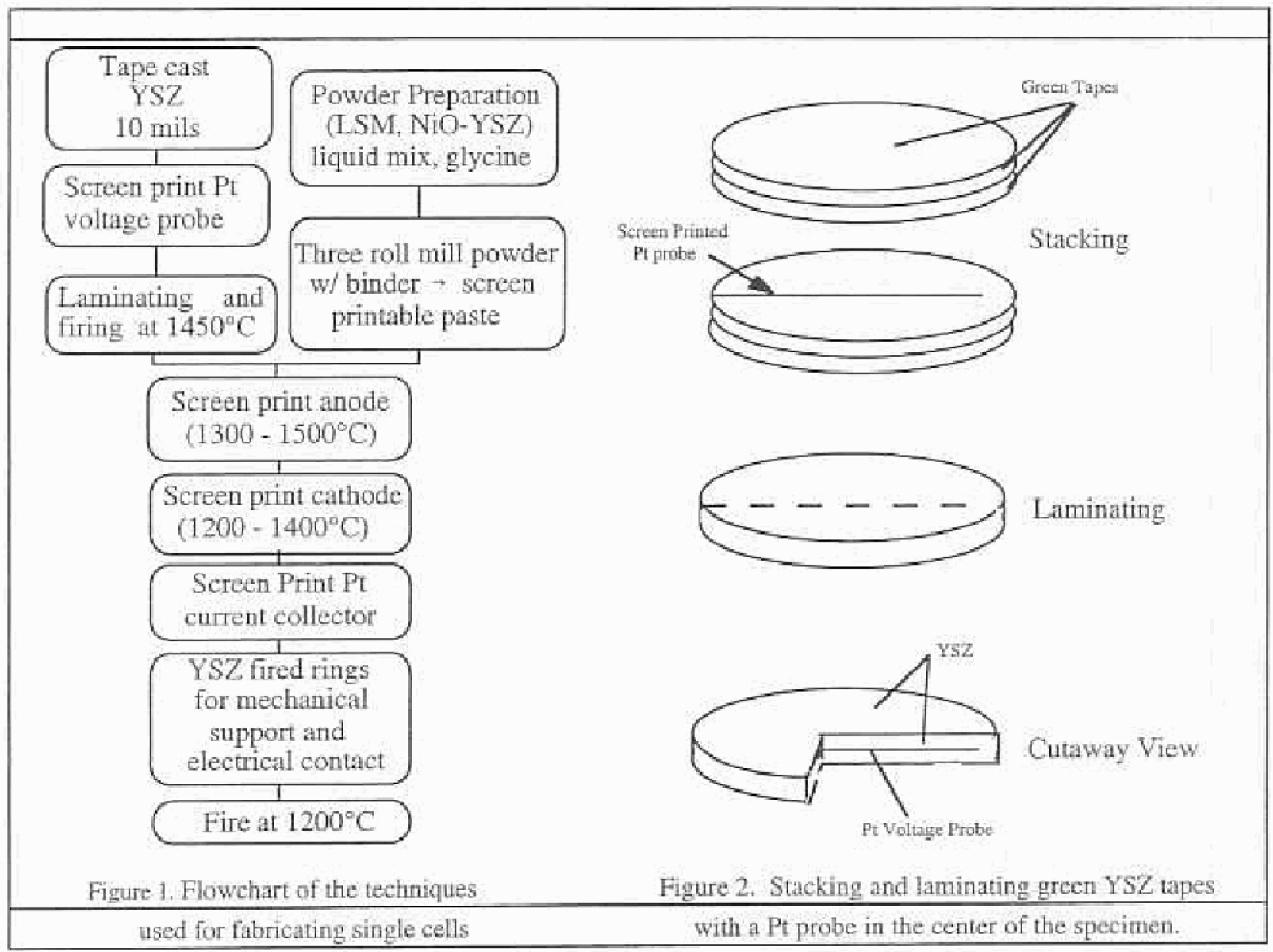

underwent a shrinkage of $-25 \%(x-y)$ during densification. The Pt voltage probe was centered internally $100 \mu \mathrm{m}$ from either surface, and was $-5 \mu \mathrm{m}$ thick and $200 \mu \mathrm{m}$ wide.

\section{Anode deposition}

The anode powders were mxed with a commercial resin solution, BX018-16, fron Ferro Corp. The suspension was mixed using a three roll mill to prepare a well-dispersed paste for screen printing. The wt loading of powder to binder varied depending on the caleination temperature and resultant surface area of the powder and was therefore performed on a trial and error basis. In all instances the highest amount of powder was loaded into the binder such that the paste was still workable.

Anode compositions were screen printed onto dense YSZ electrolytes and sintered at various temperatures. Stainless steel screens of 165 mesh, 3 mil emulsion thickness were used. Anode compositions were sintered onto the electrolyte between $1300^{\circ} \mathrm{C}$ and $1500^{\circ} \mathrm{C}$ in $100^{\circ} \mathrm{C}$ increments for a $1 \mathrm{~h}$ hold, with a heating and cooling rates of $3^{\circ} \mathrm{C} / \mathrm{min}$. A primary goal of this investigation was to vary the grain size and porosity of clectrode microstructures and the their impact on electrode performance, therefore powders were calcined and sintered at various temperatures. Anodes were porous, exhibited grain sizes on the order of $1 \mu \mathrm{m}$, and gave resultant dimensions of $0.635 \mathrm{~cm} \times 0.635 \mathrm{~cm}$ and $-20 \mu \mathrm{m}$ thick. Fracture surfaces were characterized by a JEOL Scanning 
Electron Microscope to examine resultant microstructures. All specimens wers sputtered with $\mathrm{Pd} / \mathrm{Au}$ before analysis.

\section{Mecharical Support and Electrical Connection}

A Pt grid ( $0.2 \mathrm{~mm}$ line width and $0.2 \mathrm{~mm}$ spacing between lines) was screen printed on the electrodes for eell performance experiments to act as a emrent collector but also to allow gas diffusion to the electrode/electrolyte interface.

Tape cast and fired YSZ rings ( $-350 \mu \mathrm{m}$ thick) were bonded to both sides of the electrolyte using a ceramic adhesive, Aremco 516, Figure 3 . The adhesive is a zirconia based cement which allowed themal cycling without delamination of the rings from the electrolytes. The rings acted as both mechanical support for the electrolyte and for electrical connection. The mullite tubes used for atmosphere control were cemented to the rings rather than the electrolyte so that no adhesive was in the vicinity of the active region of the cell. The rings were designed with pads which were coated with Pt paste to allow for electrical sensing. Pt wires of 10 mil diameter wete bonded from the $\mathrm{Pt}$ grid to the Pt pads on the rings using Pt paste, this was done to both the anode and cathode side of the electrolyte. Pt paste was also used to paint a conductive strip from the Pt voltage probe to a pad on the ring for voltage sensing. There are two pads on the cathode side, one for electrical connection to the cathode and one for sensing the voltage probe, whereas only one pad was active on the anode side. The cell was sintered at $1200^{\circ} \mathrm{C}$ for i h to densify the Pt and achieve a good bond between the YSZ rings and clectrolyte.

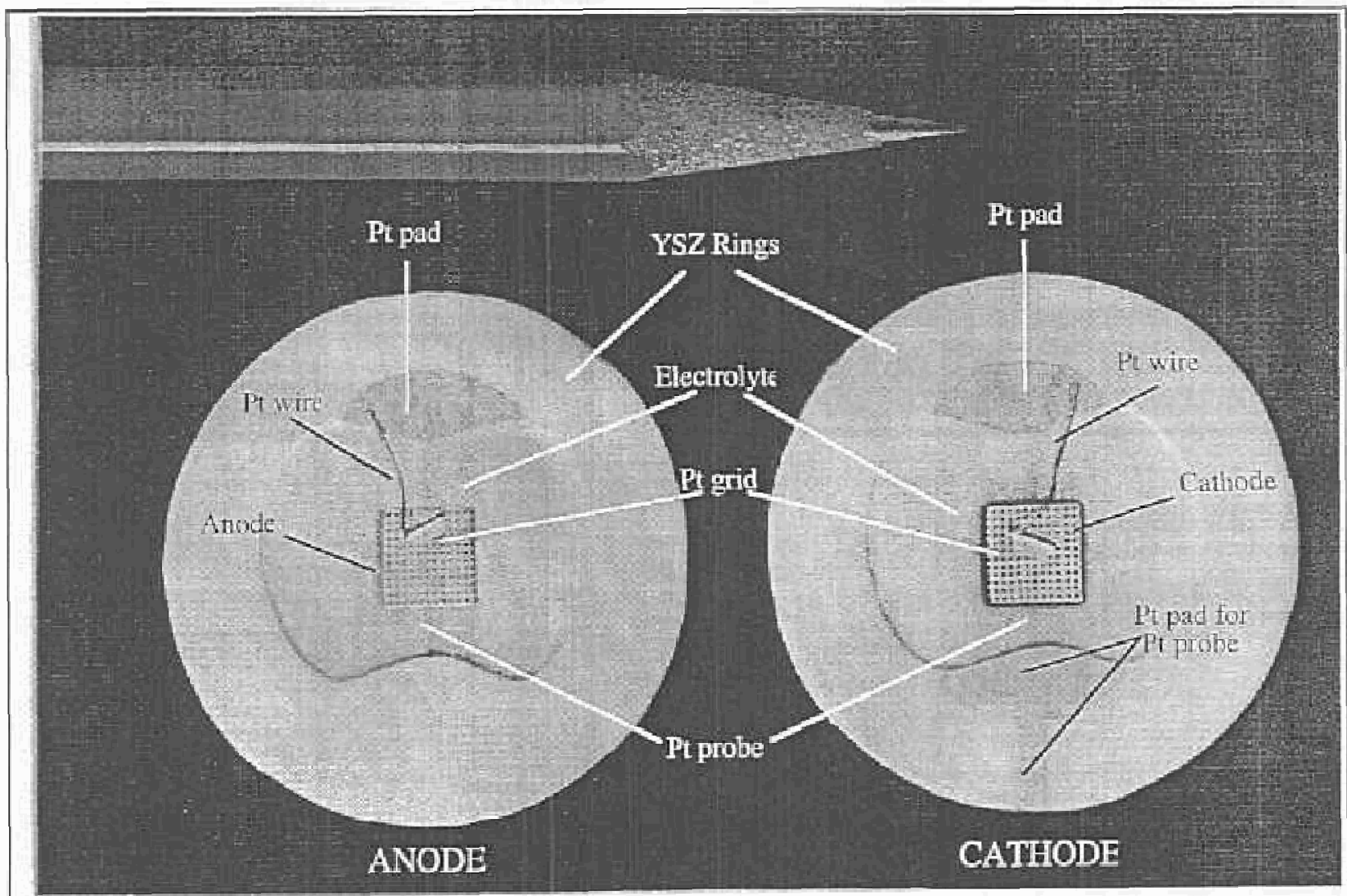

Figure 3. Photograph of the YSZ rings bonded to the electrolyte for mechanical support and clectrical contact. 


\subsection{Electrical Characterization}

Electrical chanactetization of single cells utilizing the intemal $\mathrm{Pt}$ voltage probe was investigated to simultaneously separate the losses attributed to each component (anode, electrolyte, cathode) and their interfaces (cathode/electrolyte and anode/electrolyte) during cell operation. Cell performance studies were focused on the reaction kinetics at the interfaces whereas DC conductivity measurements were performed to inyestigate the resistive losses of each component as a function of time, composition, and preparation condition.

\section{Cell Porformance Studies}

Electrochemical (I-V) measurements were carried out using a five electrode configuration which allowed for separation of anode and cathode overpotentials during operation, Figure 4. Separate leads were used to carry the cunent and voltage of the coll to remove the loss associated with the lead wires and allow for a direct examination of the losses attributed to the cell components. The third voltage lead was connected to the voltage probe and was used to monitor the voltage drop between the probe and corresponding electrodes during operation. Pt wires were used on the cathode side, four 20 mil wires for the current lead, and 10 mil wires for both the voltage leads, cathode and intemal Pt probe. Ni wires were used on the anode side, two 20 mil wires for the current lead and a 10 mil wire for the voltage lead. Both voltage leads for the cathode and anode were designed to nimie a spring for contact with the Pt grids.

I-V behavior and AC impedance spectroscopy were performed on both half cells and complete cells. The I-V behawior was measured using an Anatronics Current/Voltage Control Fuel Cell Testing Module, a Keithley Model 196 Microvoli Meter, and a Fluke 27/FM Multimeter. The Fuel Cell Testing Module was placed in the voltage control mode thus enabling the desired cell voltage and corresponding current to be measured.

After the cell was heated to $1000^{\circ} \mathrm{C}$ at $-2^{\circ} \mathrm{C}$ min, air was first fed to the cathode and then the fuel was introduced to the anode. The fuel was delivered to the anode for at least thirty minutes

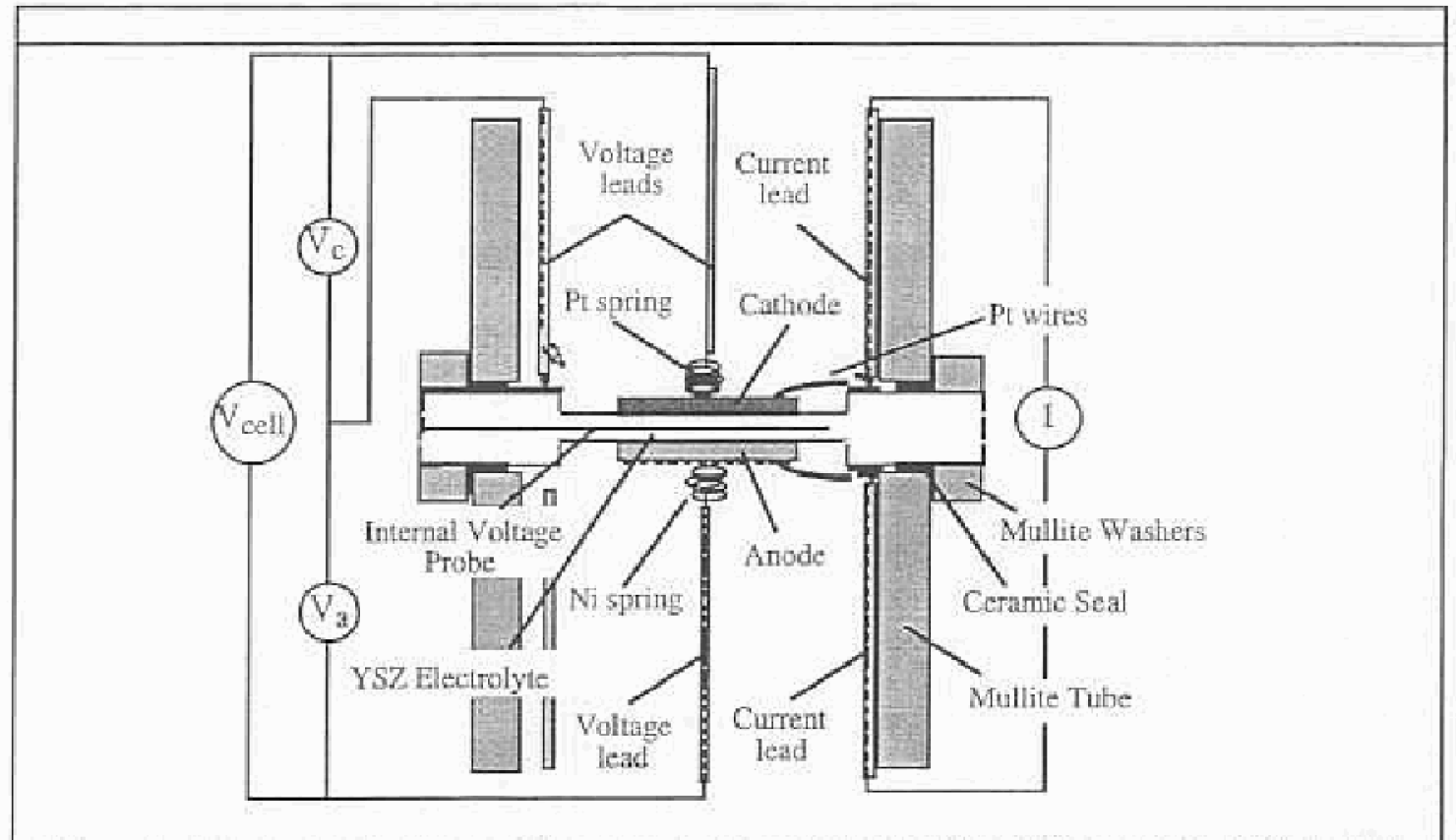

Figure 4. Experimental set up used for measuring the electrochemical (I-V) behavior of single cells. 
before electrical contact was mide to ensure that the anode (YSZ-NiO) was reduced to the cermet (YSZ-Ni). It could also be detemined at this time if the electrolyte was cracked or the sealant had failed. The resistance between the voltage and current leads of each corresponding electrode was measured before testing to ensure that each lead was still connected to the Pt grid and thus the electrode.

After all electrical connections were made the first test was to measure the open circuit, Nemst potential between the anode and cathode. The Nernst potential is very sensitive to the chemical potential gradient and hence reveals whether at small hairline fracture had occurred. It was often difficult to tell this by monitoring the exit ball flow meters and were thus a better test for fractures or leaks. Measurements were carried out from small voltages to larger ones in increments of $25 \mathrm{mV}$ and in all cases steady state voltages and currents were measured. Stabilization times were on the order of 2-3 min. The current, total cell voltage ( $\mathrm{V}_{\text {cell }}$ ), voltage drop from the $\mathrm{Pt}$ probe to the cathode $\left(\mathrm{V}_{\mathrm{c}}\right)$ and the anode $\left(\mathrm{V}_{\mathrm{a}}\right)$ were all simultaneously measured. At open circuit and at any given voltage under load the total cell voltage was equal to the two half cell voltages.

\subsection{RESULTS AND DISCUSSION}

The primary focus of this research was to reduce the sintering of the Ni particles, increasing the number of reaction sites, which would result in a lower overpotential. Electrical conductivity and $\eta$-j plots were monitored for a $24 \mathrm{~h}$ period to better understand the coarsening between Ni particles. Conductivity experiments were used to reveal how the Ni particles were distributed throughout the cemet. Since the conductivity is controlled by the Ni, these experiments help to determine if the YSZ suppoit structure was sufficient in reducing the tendency of the Ni particles to sinter. Electrochemical measurements, $\eta-1$, were not only used to determine resultant overpotentials, but also how the Ni-YSZ particle contacts were distributed in the composite.

\subsection{Resistive (IR) Contribution from the Anode}

Four point DC conductivity experiments were performed on anode compositions to determine the resistive loss associated with the anode during cell operation. Anode conductivities ranged from $-3-800 \mathrm{~S} / \mathrm{cm}$ which depended on the starting raw materials, the fabrication technique, and the sintering temperature. Figure 5 is a typical $\mathrm{V}$-I plot of an anode demonstrating ohmic behavior. Knowing the dimensions of the anode as shown previously for the case of the cathode, area $=0.4$ $\mathrm{cm}^{2}$ and thickness $=-20 \mu \mathrm{m}$, the resistance was calculated. In the worst case scenario, $\sigma=3$ $\mathrm{S} / \mathrm{cm}$, the resistance was $1.7 \mathrm{~m} \Omega$ resulting in a voltage drop of $0.7 \mathrm{mV}$ at a current density of 1000 $\mathrm{mA} / \mathrm{cm}^{2}$. Similar to the case for the cathode, the ohmic portion of the cathode is very small and cannot be resolved from the total measured voltage. Therefore, the measured voltage as a function of current density between the anoce and the Pt voltage probe can be atuributed to the resistive loss with the electrolyte ( $100 \mu \mathrm{m}$ thick) and the overpotential of the anode.

\subsection{Effect of Vol \% $\mathrm{Ni}$}

Compositions studied for this experiment ranged from $40-55 \mathrm{vol} \% \mathrm{Ni}$ in increments of $5 \mathrm{wol}$ \%. All samples were prepared from commercially available YSZ and NiO powders synthesized by the glycine nitrate process followed by calcined at $900^{\circ} \mathrm{C}$. All samples were fabricated in the form 
of oxides, sintered on the YSZ electrolyte at $1400^{\circ} \mathrm{C}$, and then reduced in situ. After the fuel was introduced to the anode, the cell was allowed to stabilize for $-1-3 \mathrm{~h}$ before electrochemical

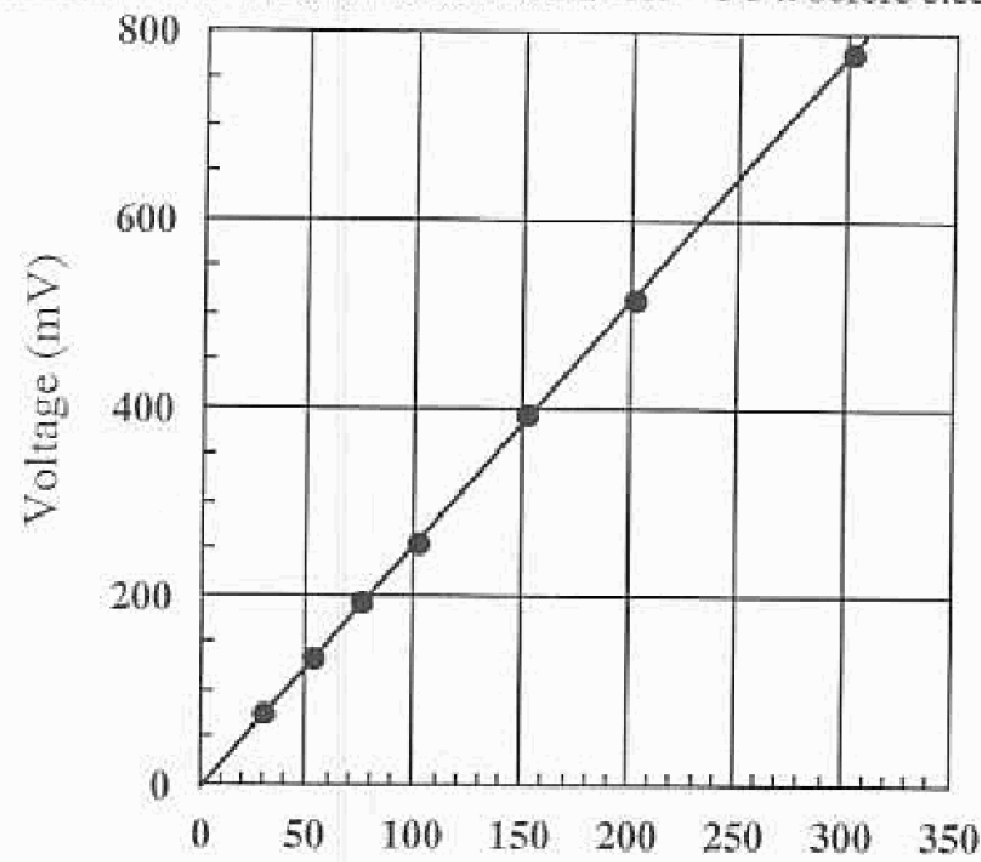

Current ( $\mathrm{mA})$

Figure 5 voltage-current behavior for a typical Ni-YSZ cermet.

measurements were performed. Conductivity experiments were monitored in air, during reduction of $\mathrm{NiO}$ to $\mathrm{Ni}$, and under reducing conditions for $24 \mathrm{~h}$.

The electrochemical response of the four compositions is shown in Figure 6 . The 40 and 45 vol \% Ni samples show similar behavior, $-220 \mathrm{mV}$ and $200 \mathrm{mV}$ at $1000 \mathrm{~mA} / \mathrm{cm}^{2}$, but the 50 and $55 \mathrm{vol} \% \mathrm{Ni}$ compositions showed much highet overpotentials, -280 and $370 \mathrm{mV}$ at 1000 $m A / \mathrm{cm}^{2}$. After $24 \mathrm{~h}$, the overpotentials of all compositions increased. Figure 7 . The 40 and 45 vol \% Ni samples still show similar behavior, $-270 \mathrm{mV}$ at $1000 \mathrm{~mA} / \mathrm{cm} 2$, and the 50 and 55 vol $\%$ Ni compositions had overpotentials of -370 and $470 \mathrm{mV}$ at $1000 \mathrm{~mA} / \mathrm{cm}^{2}$. The low vol \% $\mathrm{Ni}$ samples, 40 and 45 , have the lowest overpotentials due to the larger YSZ content in the cermet to support the $\mathrm{Ni}$ particles. This would effectively reduce the amount of sintering between $\mathrm{Ni}$ particles. For compositions with larger vol \% Ni (i.e. 55 vol \% Ni), less YSZ is available to support the $\mathrm{Ni}$ and larger $\mathrm{Ni}$ particles would be expected. The resultant microstructures for the four compositions after 24 h of operation are shown in Figures 8 and 9 . It is diffieult to see any distinguishable difference for the three lowest $\mathrm{Ni}$ conterts, 40,45 , and $50 \%$, although, the $55 \%$ composition does show a dissimilarity. The Ni particles are larger and more easily distinguishable from the YSZ suppoit.

The two end members, pure YSZ and NiO, were also examined to demonstrate the extent that the pure Ni particles coarsen and to better understand the Ni-YSZ microstructures. The YSZ and NiO samples were prepared as pastes, screen printed, sintered on the YSZ support at $1400^{\circ} \mathrm{C}$, and reduced at $1000^{\circ} \mathrm{C}$ for $24 \mathrm{~h}$. The results are shown in Figure 10. The Ni particles have sintered extensively with grain sizes of - 5mm, and the YSZ has formed a rigid strueture for supporting the Ni particles. Comparing Figure 10 with Figures 8 and 9, it has been illustrated the tremendous importance of adding YSZ to the Ni to reduce the sintering between Ni particles. To further 
demonstrate the large driving force for the Ni particles to densify, the same NiO powder was compacted into a pellet and placed into a furnace at $1000^{\circ} \mathrm{C}$ under reducing conditions for 8 hours.

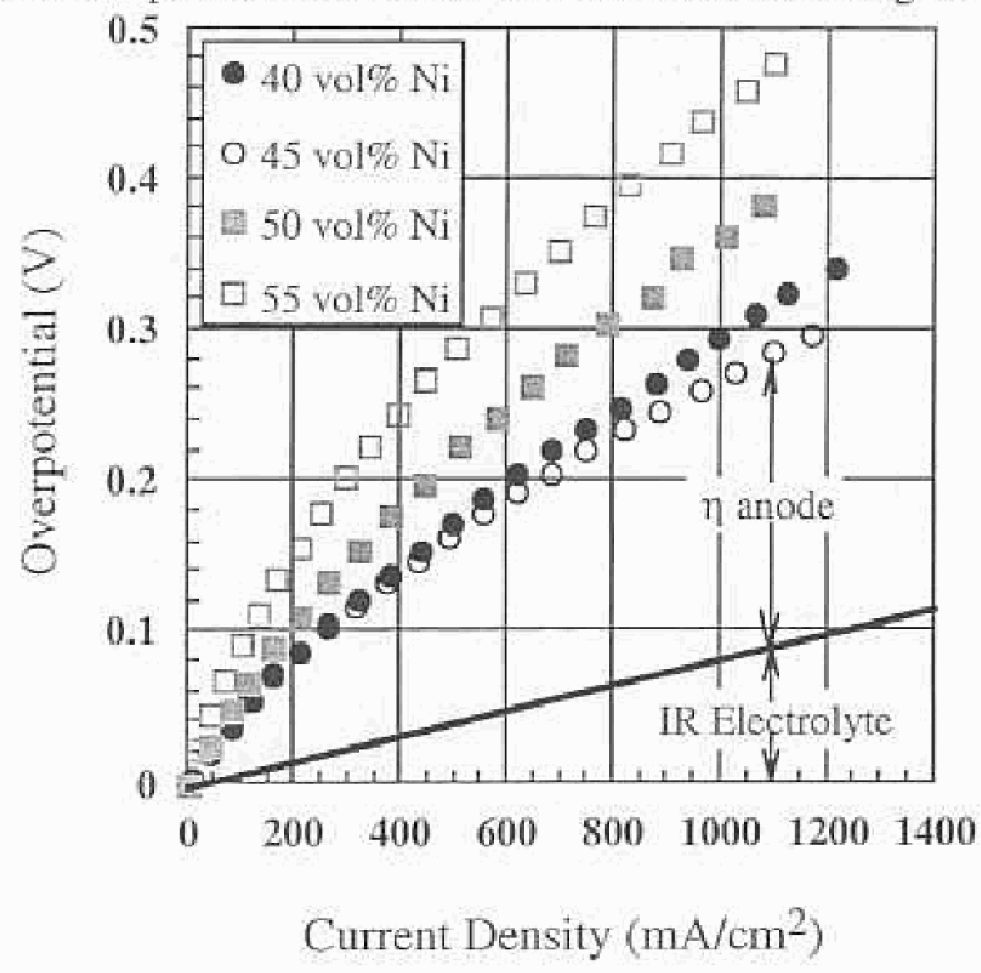

Figure 6. Initial inj relations of $\mathrm{NI}$ - YSZ cermets with various Ni contents sintered at $1400^{\circ} \mathrm{C}$ 


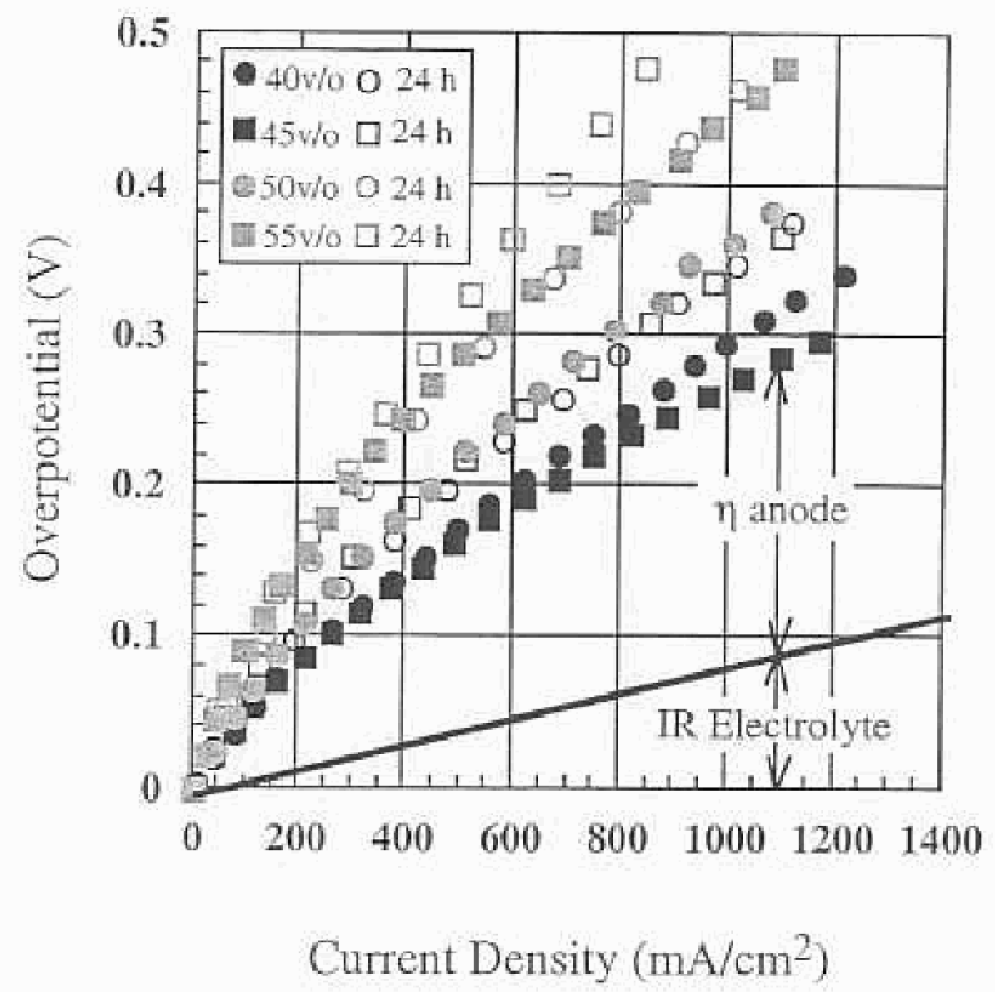

Figure 7. T-j results, inicialiy and after $24 \mathrm{~h}$, for N1-YSZ cermets with warious Ni contents sintered at $1400^{\circ} \mathrm{C}$.

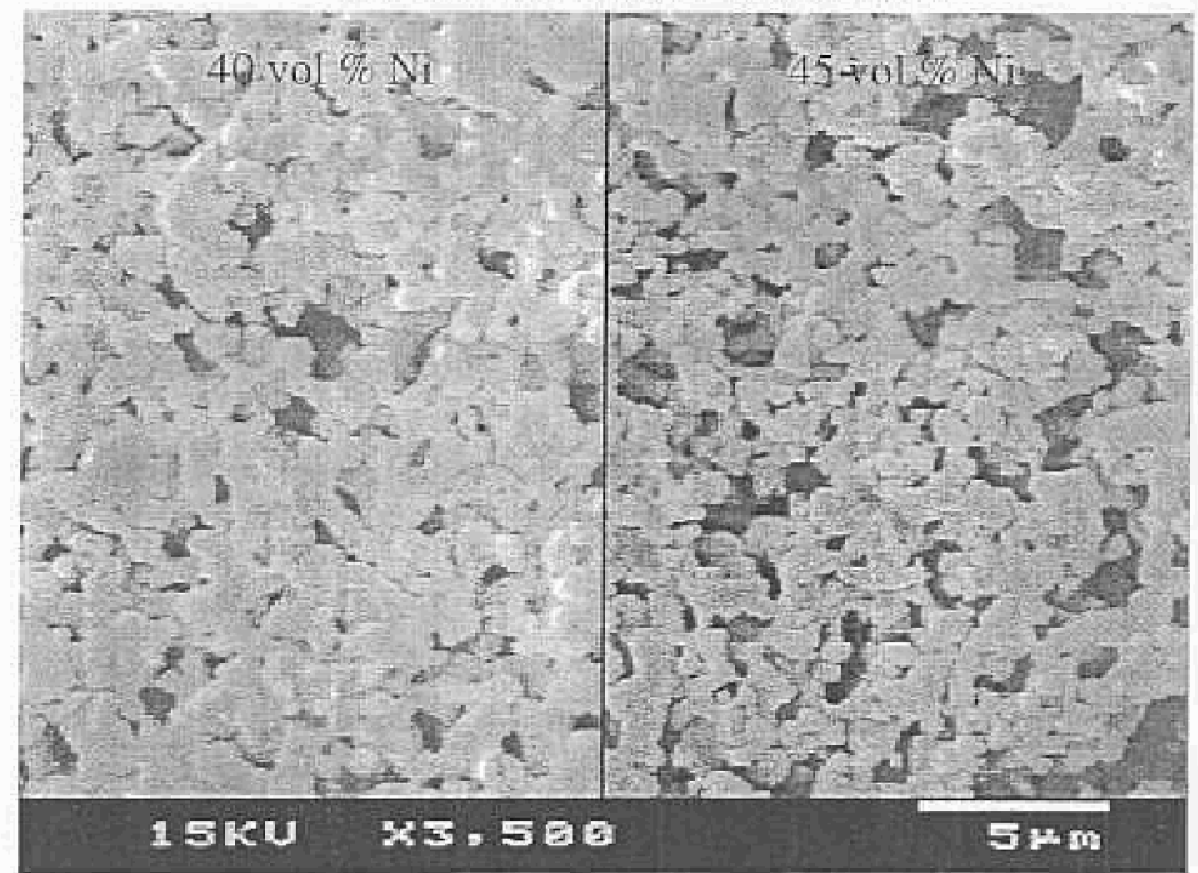

Figure 8. Microstuctures of 40 and 45 vol $\%$ Ni compositions sintered on the YSZ electrolyte at $1400^{\circ} \mathrm{C}$. 


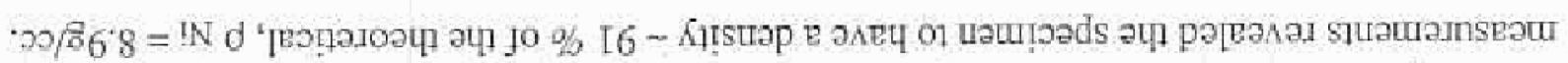

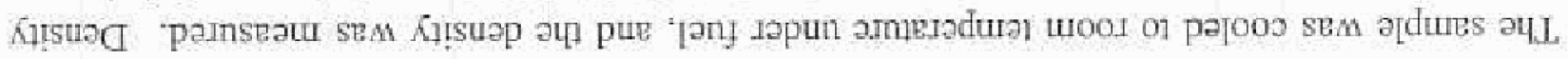

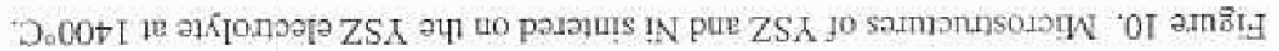

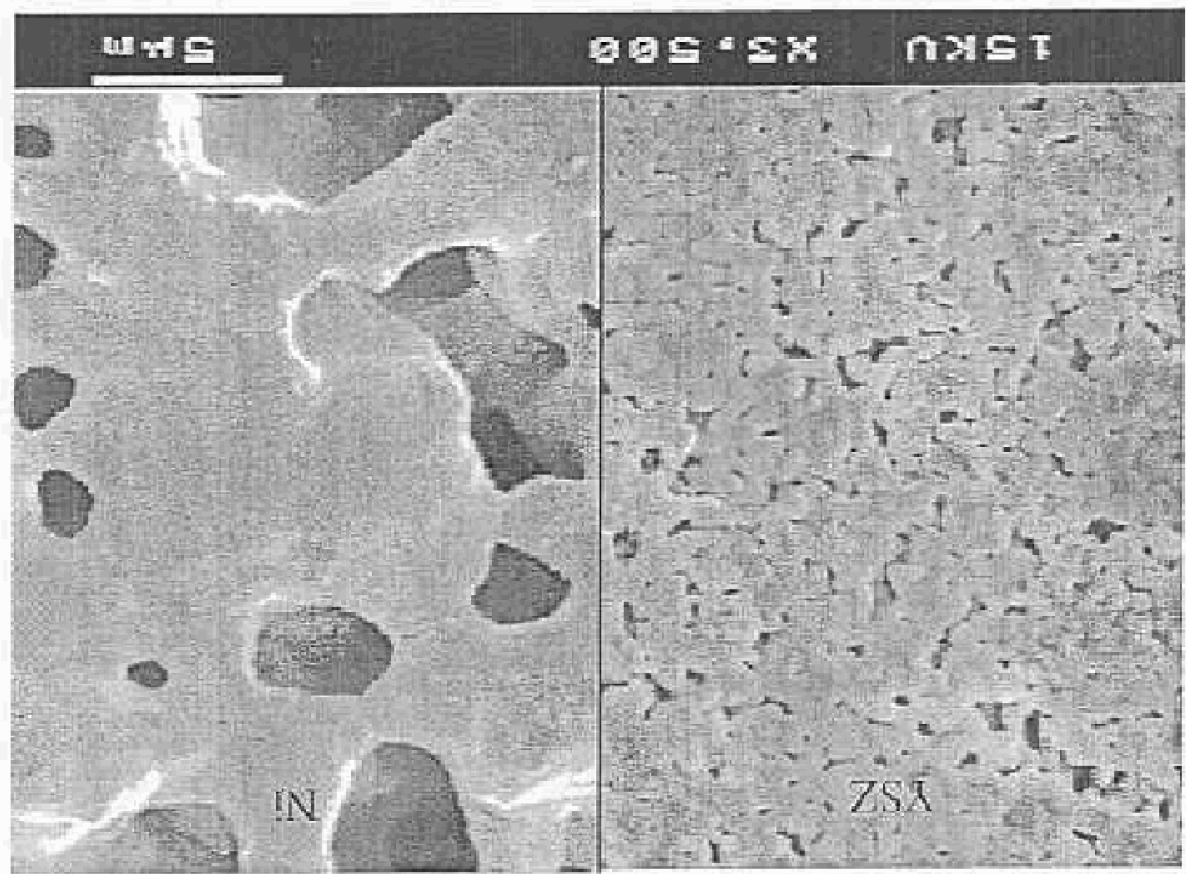

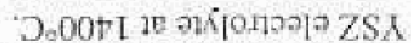

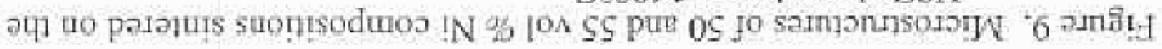

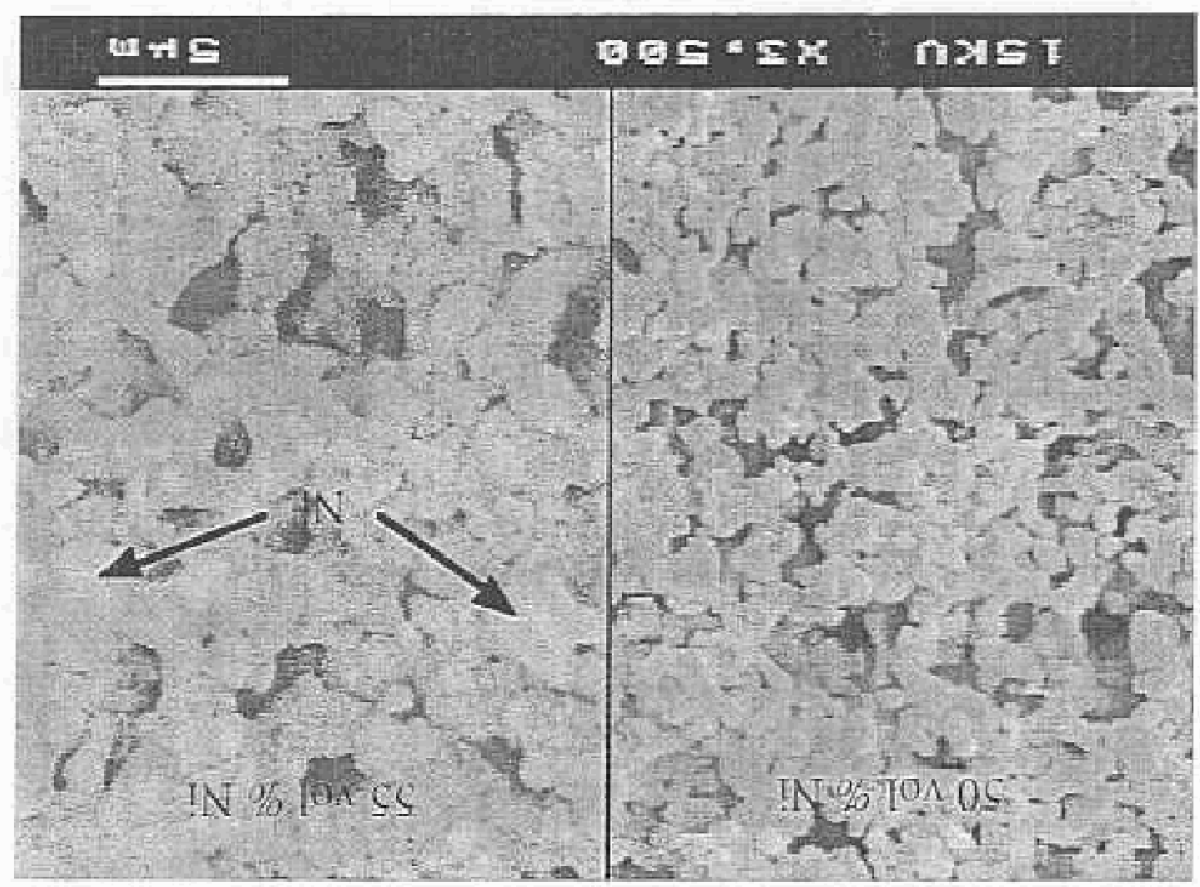


Electrical conductivity measurements were also performed on all four compositions for $24 \mathrm{~h}$, Figure 11. Since the samples contain various vol $\%$ Ni, a direct comparison cannot be made as to how the Ni particles are distributed within the cermet, although, similar trends were observed. All compositions had similar conductivities in the oxide form, $-3-5 \mathrm{~S} / \mathrm{cm}$. Upon exposure to the fuel, a large increase in the conductivity occurred, within 5 minutes, then rapidly decreased within $\sim 3$ hours to a steady state value. The large increase in the conductivity is caused by the reduction of $\mathrm{NiO}$ to Mi metal. The very sharp decrease in conductivity is due to the rapid sintering between Mi particles, and the continued slow decrease in the conductivity (after -3 h) can be attributed to further sintering of the Ni particles.

\subsection{Effect of NiO Starting Raw Materials}

Three different $\mathrm{NiO}$ sources were used in this study to examine the effect of $\mathrm{Ni}$ particle size and preparation conditions on the anodie overpotential. All anodes contained 45 vol $\% \mathrm{Ni}_{\text {, and }}$ were fired onto the YSZ electrolyte at $1400^{\circ} \mathrm{C}$. The first $\mathrm{NiO}$ powder was synthesized by the glycine nitrate process and calcined at $900^{\circ} \mathrm{C}$ as described previously. The remaining two sources were commercially available powders with different primary particle sizes. The first powder had a reported particle size of -325 mesh $(<45 \mu \mathrm{m})$ and the second powder was spray dried with a primary particle size less than $10 \mu \mathrm{m}$.

The $17-j$ plots for the three different particle sizes initially and after 24 h are shown in Figure 12. The results of the powder prepared by the glycine nitrate process are the same as reported previously, Figure 7 . The -325 mesh powder inilially has an overpotential of $-250 \mathrm{mV}$ at 600 $\mathrm{mA} / \mathrm{cm}^{2}$ but increases to $\sim 370 \mathrm{mV}$ after $24 \mathrm{~h}$. The spray dried powder has a relatively stable

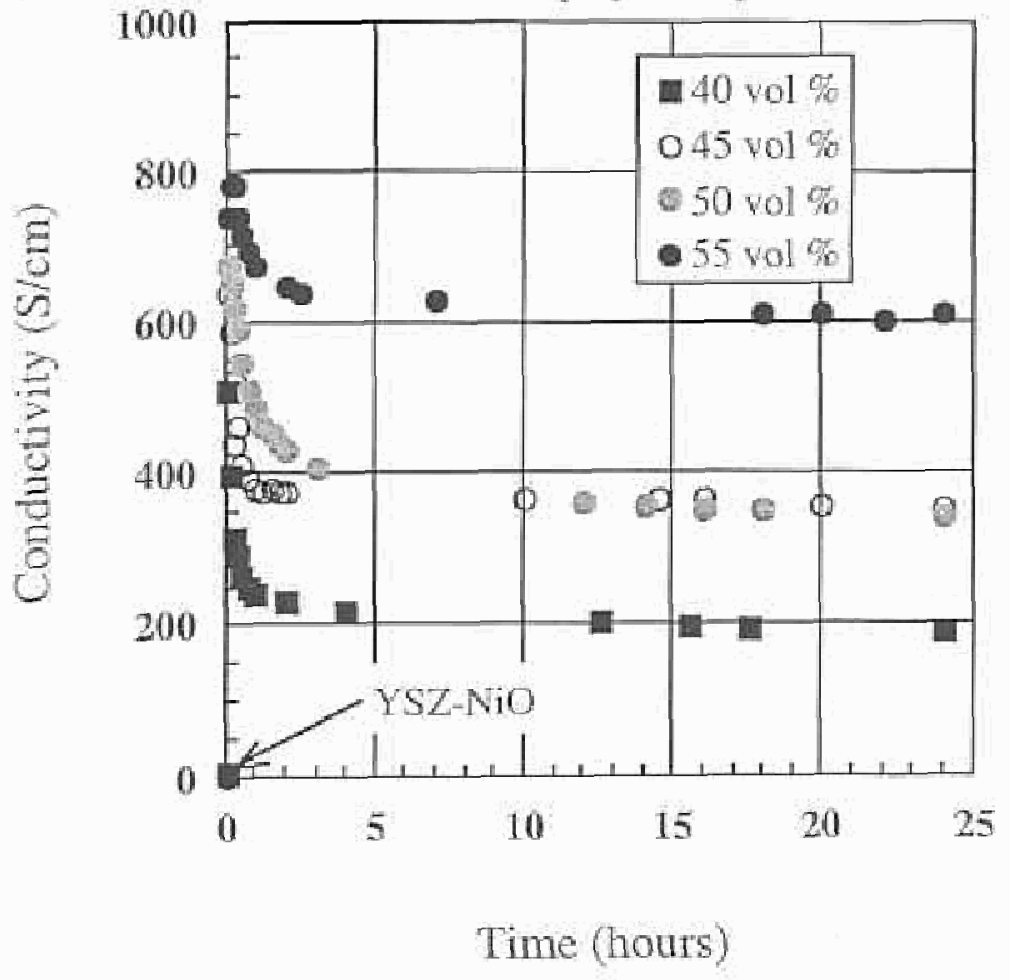

Figure 11. Conductivity versas time for Mi-YSZ cermets prepared with various Ni contenis and sintered at $1400^{\circ} \mathrm{C}$. 


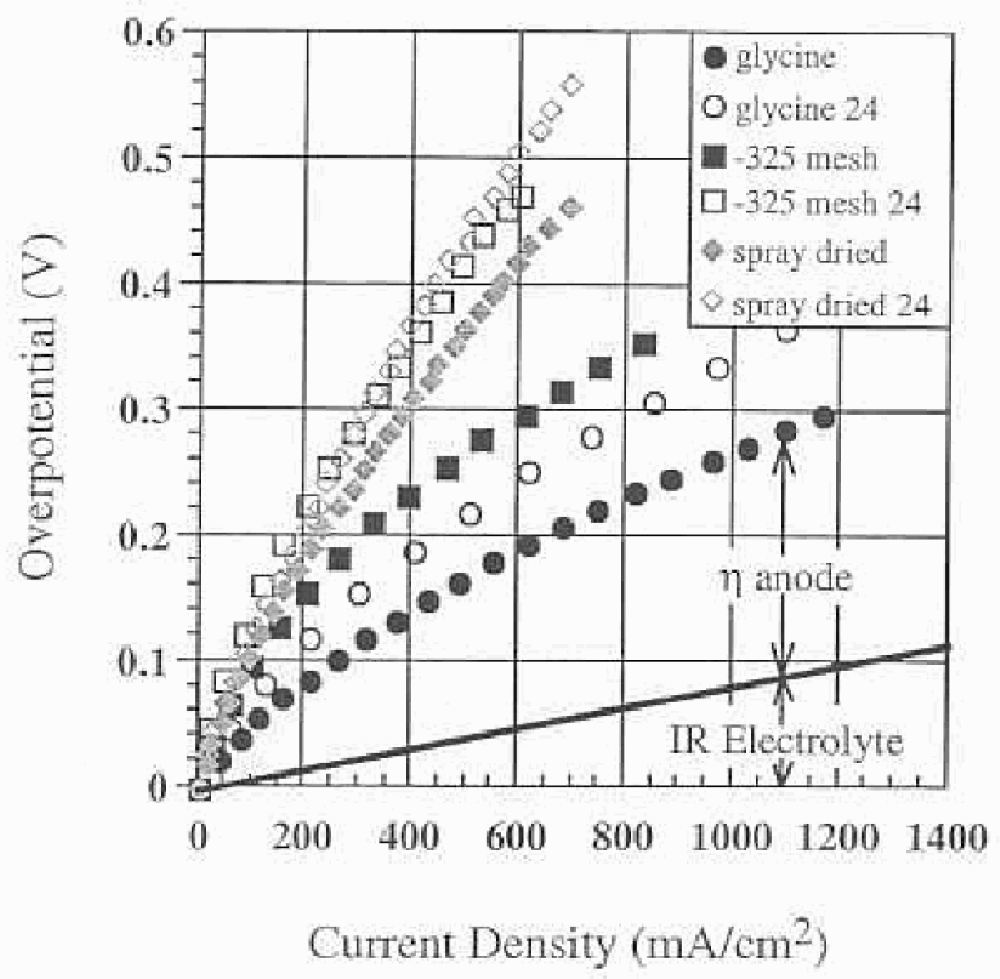

Figure 12 . 1-j relations of 45 wol $\%$ Ni compositions prepared with different NiO sources and sintered at $1400^{\circ} \mathrm{C}$.

overpotential but is extremely high, $\sim 450 \mathrm{mV}$ at $600 \mathrm{~mA} / \mathrm{cm}^{2}$. Examination of the microstructures after 24 th of operation, Figures 13 and 14 , reveals large, distinguishable $\mathrm{N}$. particles for both commercial powders. This can explain the large overpotentials in that the number of reaction sites (Ni-YSZ contacts) has drastically decreased due to the large Ni particle size. The microstructure of the spray dried powder resembles spray dried granules which eventually reduce to Ni spheres.

The conductivity for the three powders also comelates well with the electrochemical results as shown in Figure 15. The conductivity of the spray dried powder was relatively stable upon reduction but was extremely low, comparable to the NiO-YSZ composite ( 3 S/om). This suggests that the Ni particles have rapidly become large and separated from one another decreasing the number of Ni-Ni contacts. The -325 mesh powder initially had a higher conductivity ( -200 S/cmi) but quickly decrease to values comparable to the spray dried powder. This also suggest that the Ni particles have coarsened and redueed the number of $\mathrm{Ni}-\mathrm{Ni}$ contacts throughout the cermet. For both commercial powders, the Ni-Ni and Ni-YSZ particle contacts has decreased causing the conductivity to be extremely low and the overpotential to be high.

\subsection{Effect of Pre-calcination of Powders}

The influence of calcining $\mathrm{NO}$ and $\mathrm{YSZ}$ together at high temperatures $\left(1400^{\circ} \mathrm{C}\right)$ before depositing the composition onto the YSZ was next investigated. This approach was examined to provide a more stable anode structure by allowing the $\mathrm{YSZ}$ and $\mathrm{NiO}$ powders to further densify during oaloination. The powders were then milled, deposited onto the YSZ electrolyte, and sintered at $1400^{\circ} \mathrm{C}$. The composition studied was 50 vol $\% \mathrm{Ni}$, the $\mathrm{\eta}-\mathrm{j}$ results ane shown in Figure 16. For comparison, a 50 vol \% $\mathrm{Ni}$ composition prepated by the conventional technique (described previously with no pre-calcination of $\mathrm{NiO}$ and $\mathrm{YSZ}$ ) is also illustrated. Both the precalcined and conventionally prepared samples have the same starting raw materials, commercial YSZ and NiO prepared by the glycine nitrate process. The pre-calcined powders resulted in a 
lower and more stable overpotential $\left(-240 \mathrm{~m} \mathrm{~V}\right.$ at $\left.1000 \mathrm{~mA} / \mathrm{m}^{2}\right)$ than the conventionally prepared composition $\left(-380 \mathrm{mV}\right.$ at $\left.1000 \mathrm{~mA}^{-1 / \mathrm{m}^{2}}\right)$ after $24 \mathrm{~h}$. The lower and more stable overpotential is believed to be caused by a mote nigid and stronger YSZ structure due to the hingh temperature calcination of the YSZ and NiO. The pre-calcination treatment allows more densification to occur between YSZ particles because the anode is nomally constrained to sinter by the YSZ electrolyte during annesling. Therefore, the pre-calcination treatment is more effective than the conventional preparation technique in preventing the Ni from coarsening during operation. The pre-calcined and conventionally prepared anode microstructures after $24 \mathrm{~h}$ of operation are shown in Figure 17. The precalcined anode resulted in larger grains $(-1-2 \mu \mathrm{m})$ and a coarser microstructure than the conventionally prepared anode due to the high temperature calcination treatment.

\subsection{Effect of Annealing Temperature on the Anodic Overpotential}

The temperature at which the anode was sintering on the YSZ electrolyte was investigated to increase the stability of the anode over a $24 \mathrm{~h}$ period. Two composition prepared by two different techniques were examined. The first composition contained 50 vol $\% \mathrm{Ni}$ and the powders were pre-calcined at $1400^{\circ} \mathrm{C}$. The second anode was a 45 vol $\% \mathrm{Ni}$ composition prepared by the conventional technique. Both composition were fired on the electrolyte at 1300,1400 , and $1500^{\circ} \mathrm{C}$.

\section{$4.5 .1 \quad$ Pre-calcined Powders $(50$ vol o Ni)}

The electrochemical behavior of the pre-calcined $50 \mathrm{vol} \% \mathrm{Ni}$ composition fired on the electrolyte at 1300,1400 , and $1500^{\circ} \mathrm{C}$ is shown in Figure 18 . Both the initial results and those after 24 h of operation are illustrated. The $1500^{\circ}$ firing shows the best stability and lowest

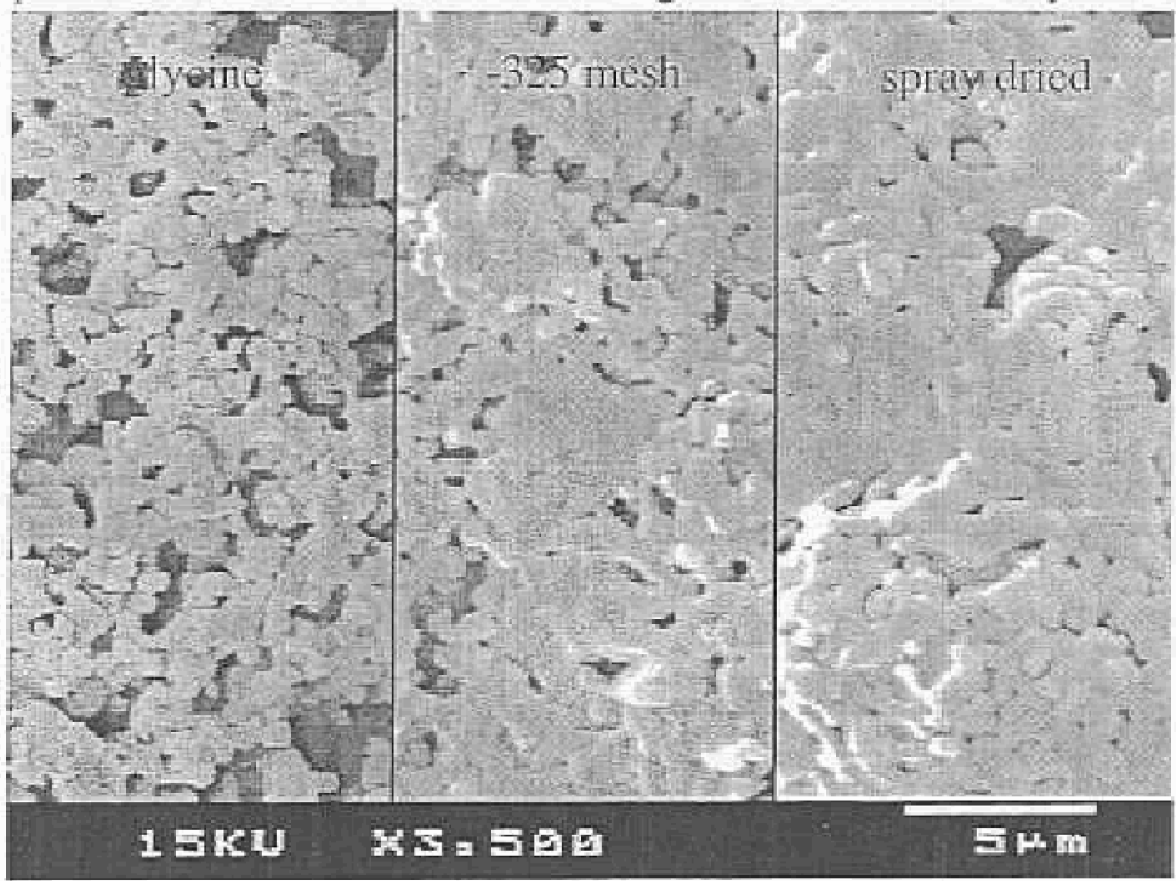

Figure 13. Microstructures of 45 vol $\%$ Ni compositions prepared with different $\mathrm{NiO}$ sources and sintered on the $\mathrm{YSZ}_{\mathrm{S}}$ electrolyce at $1400^{\circ} \mathrm{C}$. 


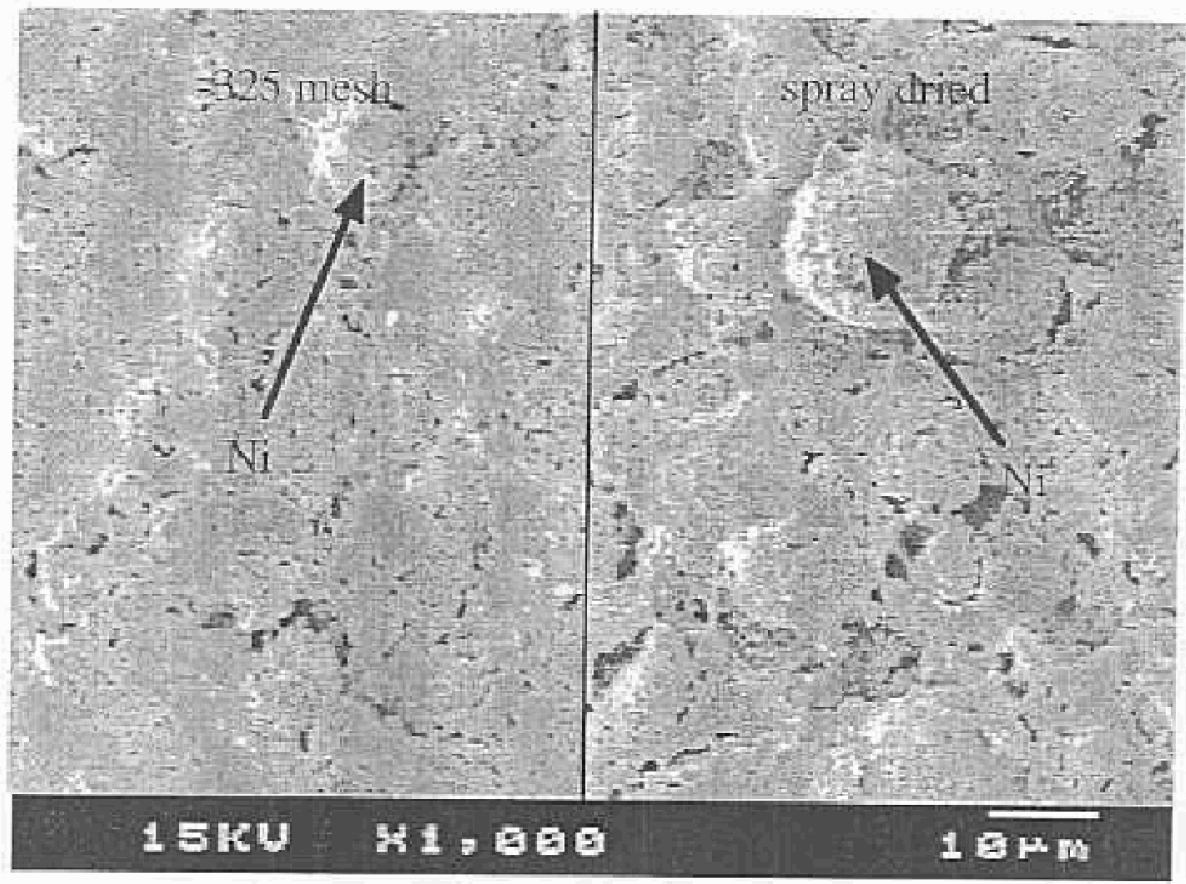

Figure 14. Microstructures of 45 vols Ni compositions prepared with two different commercial NiO sources and sintered on the YSZ electrolyte at $1400^{\circ} \mathrm{C}$.

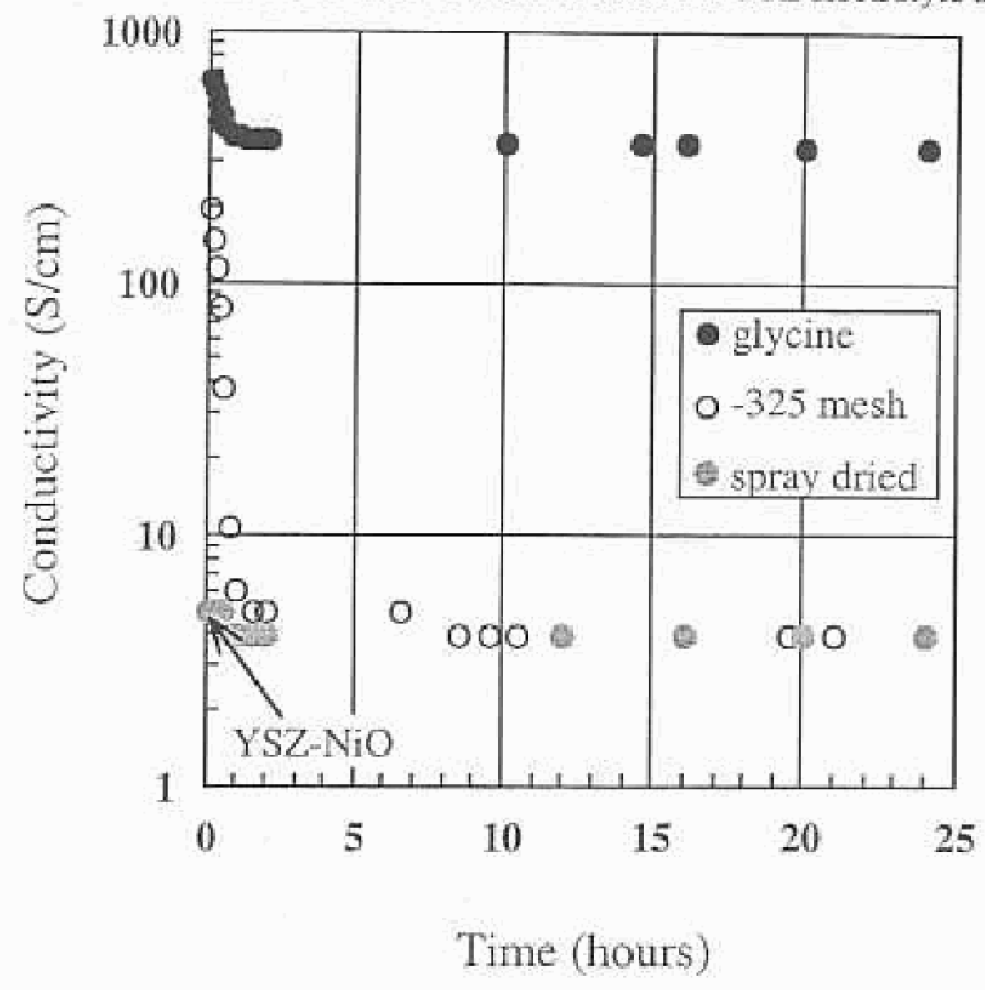

Figure 15 . Conductivity wersus time of 45 vol $\%$ Ni compositions prepared with different $\mathrm{NiO}$ sources and sintered at $1400^{\circ} \mathrm{C}$. 


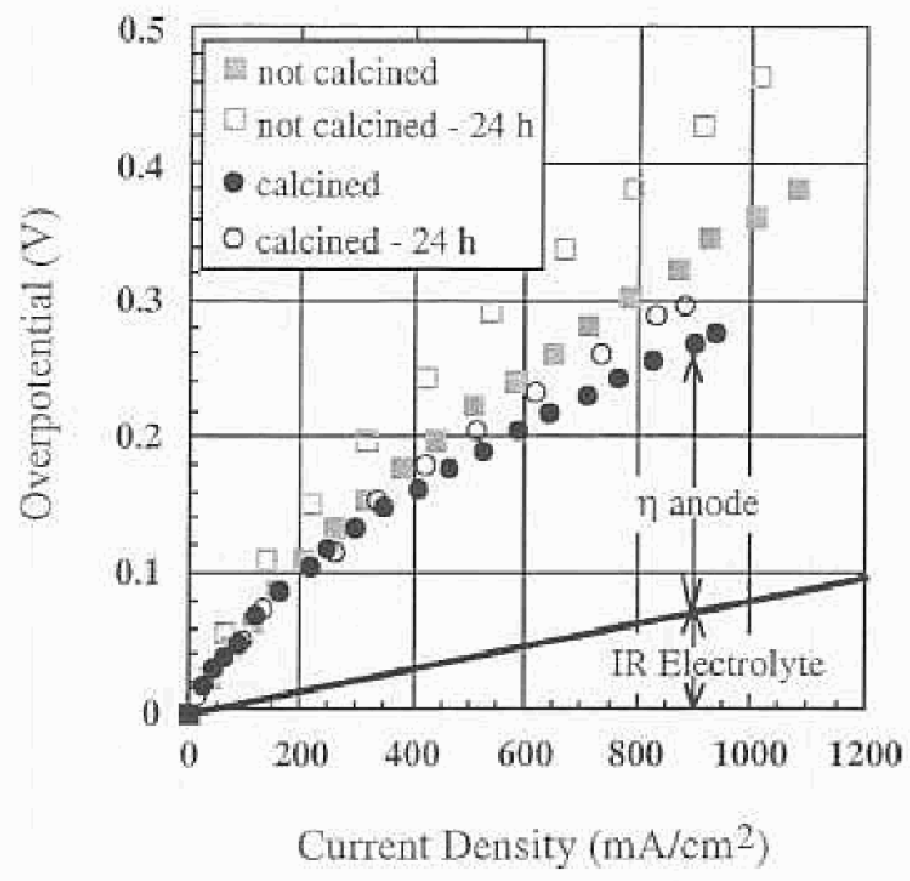

Figure 16. 7 - relations of 50 wol 5 N1 compositions prepared by different techniques, $\mathrm{NiO}$ and YSZ calcined together at $1400^{\circ} \mathrm{C}$ and by the conventional technicue, and sintered at $1400^{\circ} \mathrm{C}$

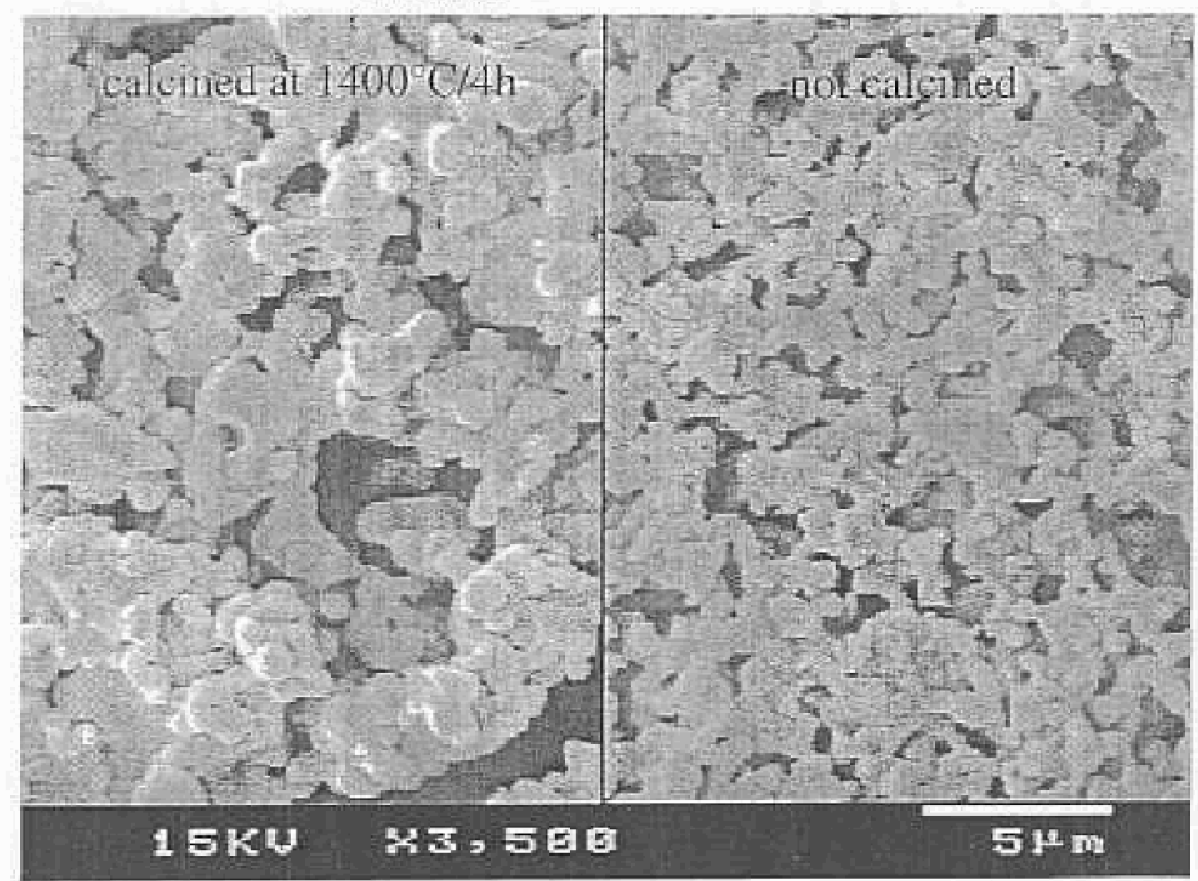

Figure 17. Microstructures of 50 vol $\%$ Ni compositions prepared by different techniques. $\mathrm{N} \mathrm{O}$ and $\mathrm{YSZ}$ calcined together at $1400^{\circ} \mathrm{C}$ and by the conventional technique, and sintered on the YSZ electrolyte at $1400^{\circ} \mathrm{C}$. 


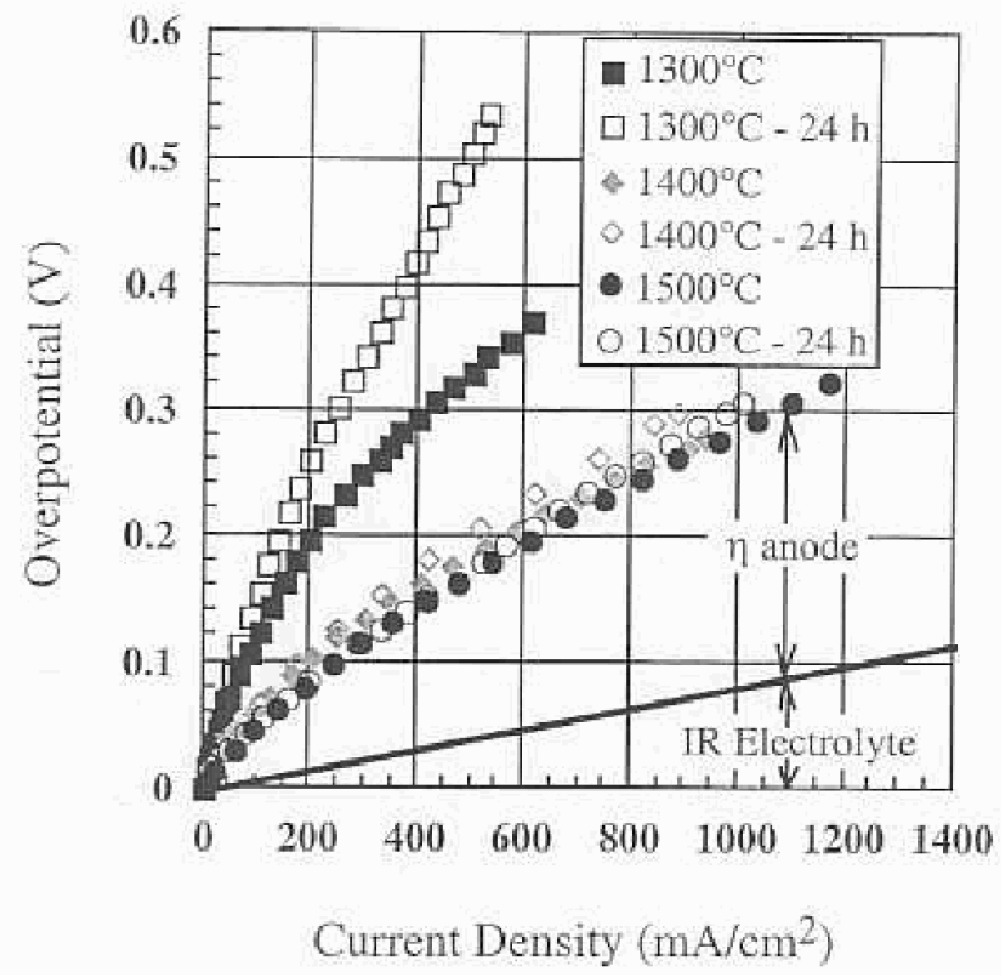

Figure 18. T-j relations of 50 wol \% $\mathrm{N}$ compositions pre-calcined at $1400^{\circ} \mathrm{C}$ and sintering at various temperatures.

overpotential alter $24 \mathrm{~h}\left(-220 \mathrm{mV}\right.$ at $\left.1000 \mathrm{~mA} / \mathrm{cm}^{2}\right)$. The anode densified at $1400^{\circ} \mathrm{C}$ also showed a low overpotential but slightly increased with time $\left(-240 \mathrm{mV}\right.$ at $\left.1000 \mathrm{~mA} / \mathrm{cm}^{2}\right)$. The sample sintered at $1300^{\circ} \mathrm{C}$ had the highest overpotential and was unstable within the $24 \mathrm{~h}$ period (- 400 $\mathrm{mV}$ at $400 \mathrm{~mA} / \mathrm{cm}^{2}$ after $24 \mathrm{~h}$ ). The improved electrochemical response with higher sintering temperatures is due to the improved sintering of YSZ particles, a more rigid YSZ support will further inhibit the Ni particles from coarsening. The densification of the YSZ support at high temperatures (1300-1500 $\mathrm{C}$ ) should provide a stable backbone and is not expected to change under fuel cell conditions ( $\left.\mathrm{pO}-10^{-17}, 1000^{\circ} \mathrm{C}\right)$.

The conductivity and microstructures after $24 \mathrm{~h}$ of operation are shown in Figures 19 and 20 , respectively. The conductiwity results comelate well with the electrochemical response, both suggesting that the sintering between $\mathrm{Ni}$ particles has been reduced with higher annealing temperatures. For higher sintering temperature, there should be better Ni-Ni particle contact resulting in more paths for conduction to occur. The microstructures also suggest that the lower firing temperature has a less rigid structure (the grains appear to be smaller and not as well bonded to one another) than the progressively higher annealing temperatures.

\subsubsection{Conventional preparation $(45 \mathrm{vol} \% \mathrm{Ni})$}

The electrochemical behavior of the-conventionally prepared 45 vol \% $\mathrm{Ni}$ composition sintered on the electrolyte at 1300,1400 , and $1500^{\circ} \mathrm{C}$ is shown in Figure 21. Both the inttial and 24 h results are illustrated. The $1500^{\circ}$ firing has the best 24 h stability and lowest overpotential ($190 \mathrm{mV}$ at $1000 \mathrm{mAN}^{2} \mathrm{~cm}^{2}$ ). The composition densified at 1400 also showed a low initial overpotential but increased substantially in $24 \mathrm{~h}\left(-270 \mathrm{mV}\right.$ at $\left.1000 \mathrm{~mA} / \mathrm{cm}^{2}\right)$. Samples sintered at $1300^{\circ} \mathrm{C}$ were stable but had high overpotentials $\left(-300 \mathrm{mV}\right.$ at $\left.1000 \mathrm{~mA} / \mathrm{cm}^{2}\right)$. The improved clectrochemical response with higher sintering temperatures can also be attributed to the improved densification between YSZ particles as described in the previous section. 
The conductivity and mierostructures after 24 h of operation are shown in Figures 22 and 23. The conductivity results also correlate well with the electrochemical response, both suggesting that the sintering between Ni paricles has been reduced with higher densification temperatures. This results in better $\mathrm{Ni}-\mathrm{Ni}$ particle contact throughout the eermet, and therefore more paths for conduction. The microstructures also suggest that the higher annealing temperature has a more tigid structure (the grains are larger, $-1-2 \mu m_{1}$ and bonded well to one another) than the progressively lower annealing temperatures.

Higher annealing temperatures $\left(1500^{\circ} \mathrm{C}\right.$ ) have demonstrated that an improved stability, lower overpotentials, and higher conductivities car be achieved for both the pre-calcined and conventional prepared anodes. A direct comparison cannot be made between the two techniques because the anodes contain different Ni contents. Although, the above results do suggest that a lower vol \% Ni (40-45) for the pre-calcined technique should be explored. This could reduce the overpotential and improve the stability at lower annealing temperatures $\left(1400^{\circ} \mathrm{C}\right)$.

\subsection{MAJOR ACHEVEMENTS DURING THE PAST YEAR}

Anode Studies:

- YSZ anodes prepared with lower Ni volume fractions $(40$ \& $45 \%$ ) resulted in lower overpotentials and improved stability.

* Higher sintering temperatures effectively lowered the overpotential and increased the in-plane conductivity. Due to constrained sintering between the anode and the YSZ electrolyte, higher 


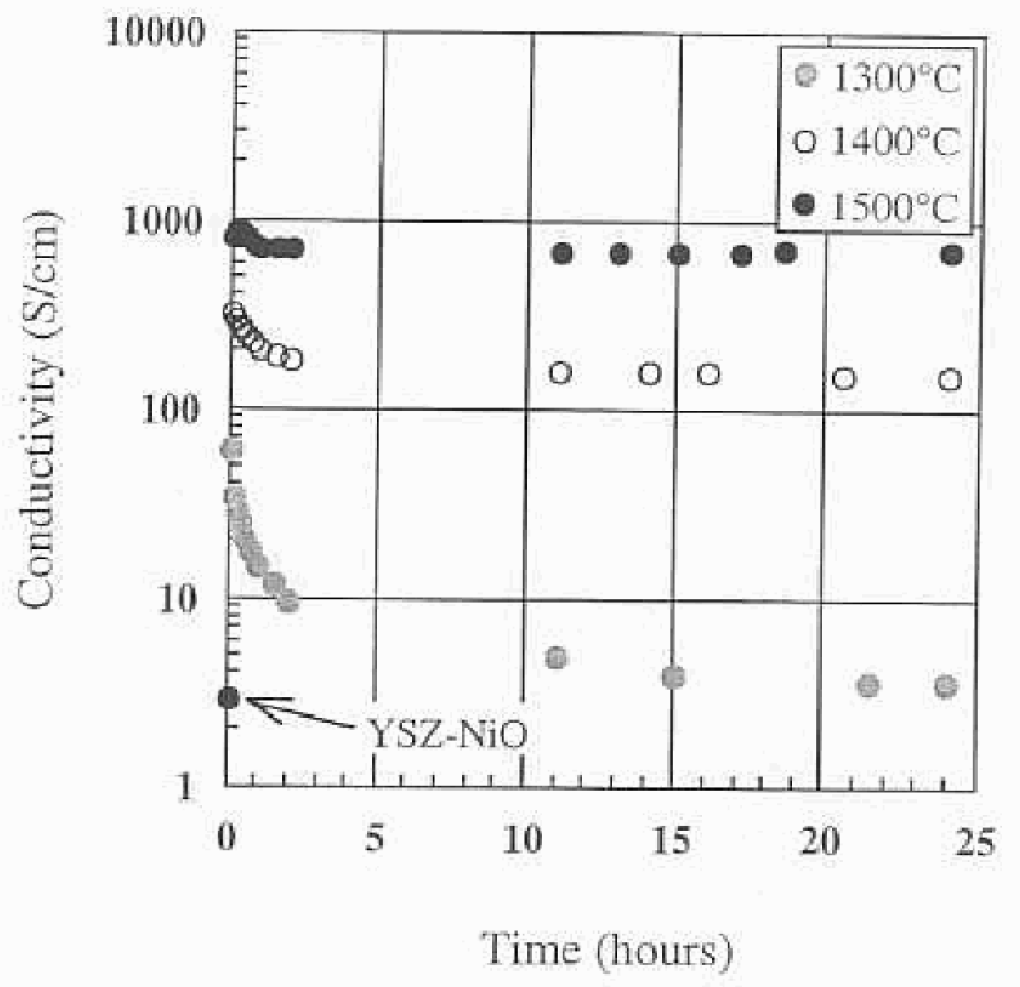

Figure 19. Conductivity versus time for 50 vol \% Ni compositions pre-calcined at $1400^{\circ} \mathrm{C}$ and sintered at various. temperatures.

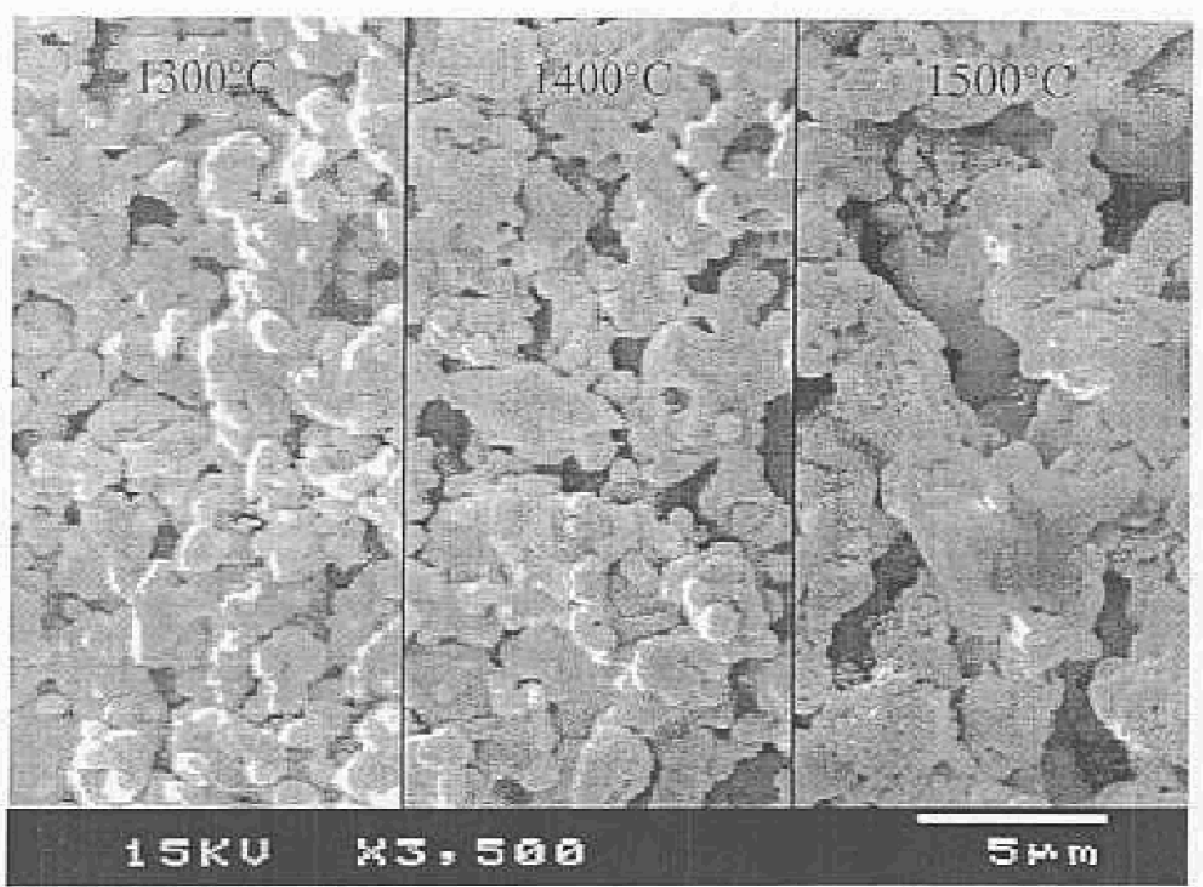

Figure 20. Microstructures of 50 wol \% Ni compositions pre-calcined at $1400^{\circ} \mathrm{C}$ and sintered on the YSZ electrolyte at various temperatures. 


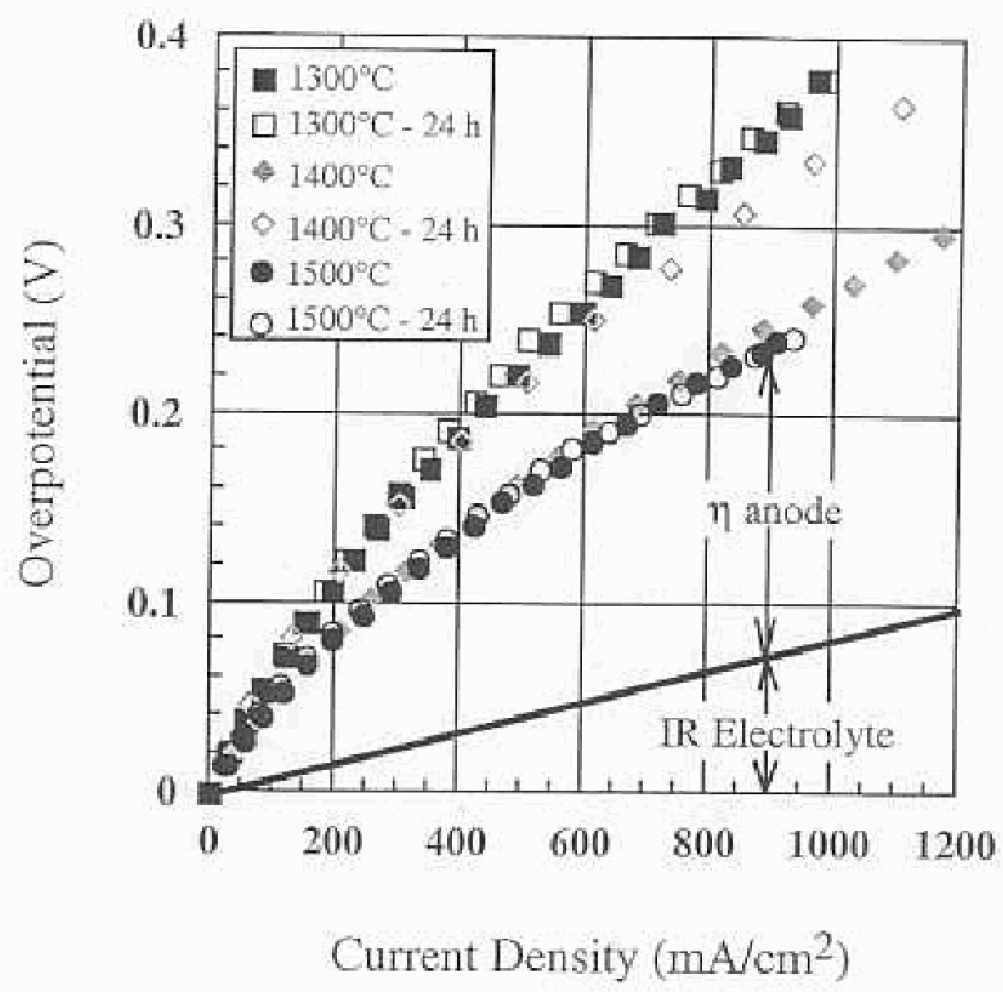

Figure 21: 7-j telations of 45 vol \% Ni compositions sintered at various temperatures.

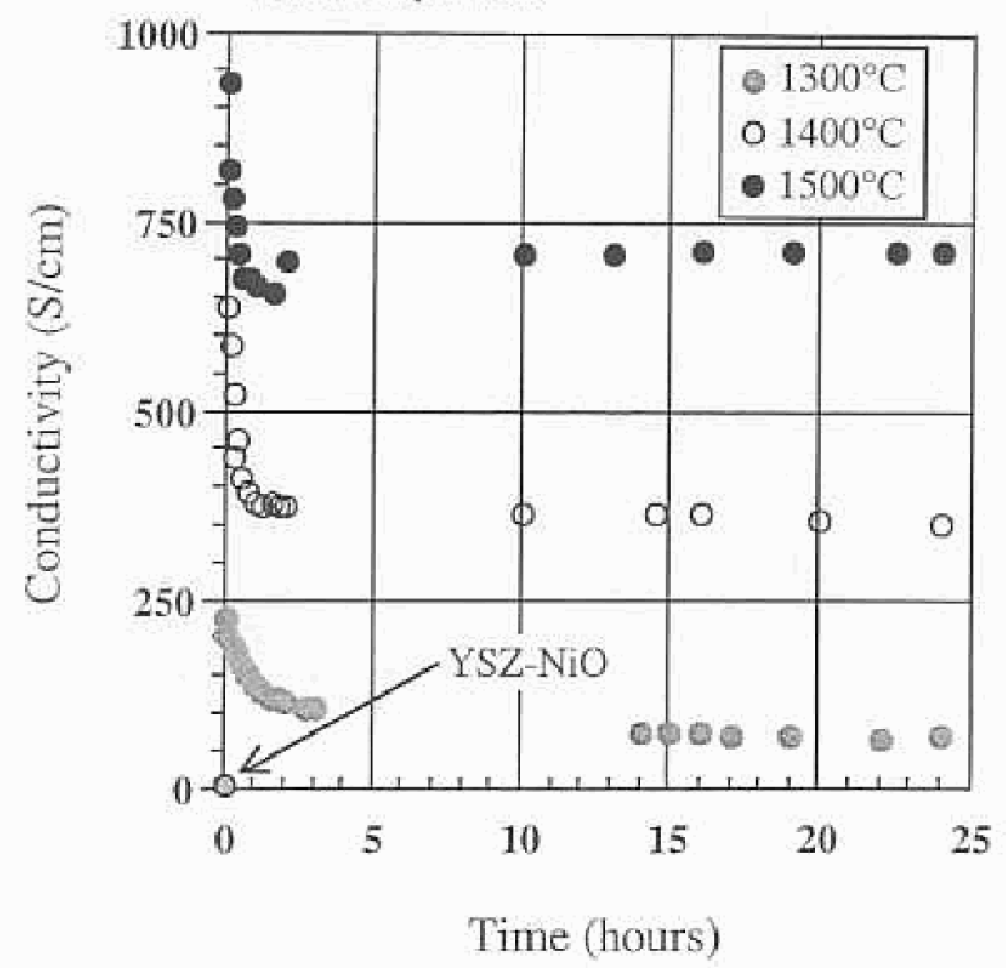

Figure 22: Conduetivity versus time of 45 vol $\%$ Ni compositions sintered at various temperatures. 


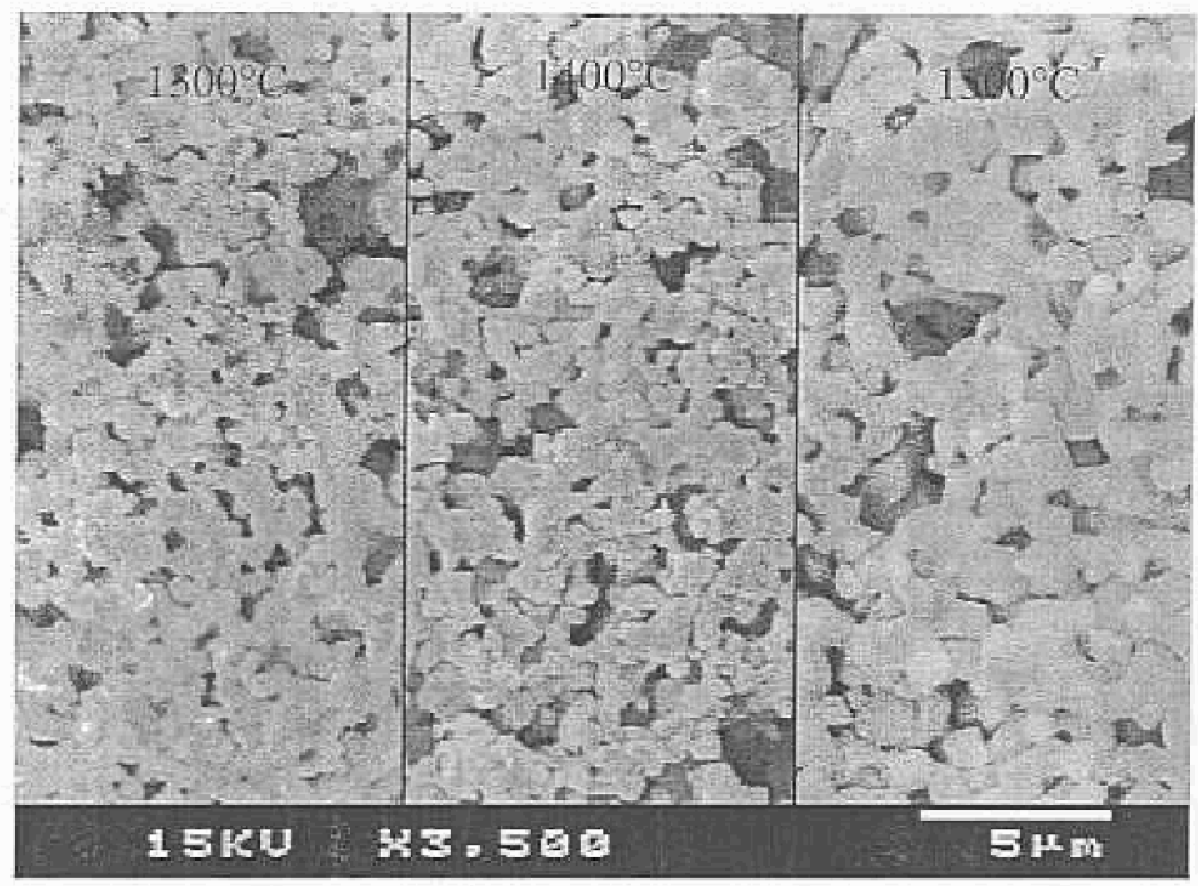

Figure 23 Mierostructures of 45 vol \% Ni compositions prepared by the conventional technique and sintered on the YSZ electrolyte at various tempetatures.

sintering temperatures allowed more densification in the Z-direction, resulting in a rigid YSZ structure to support Ni particles

- By decreasing the densification between Ni gratns, there are more paths for conduction (more Ni-Ni contacts throughout the strugture and higher conductivities) and a larger number of $\mathrm{Ni}$ YSZ contacts (lower overpotentials).

- The 45 vol\% Ni composition co-fired with the electrolyte had the lowest initial overpotential of any cermet with a similar composition.

\subsection{FutURE ACTIVITIES}

With respect to the major thrusts of this program:

- Fabricate additional single cells with controlled microstructures of the anode by co-synthesis of the YSZ and $\mathrm{NiO}$; incorporate interfacial modifications to improve the catalytic activity.

- Gain a better understanding of the mechanisms involved in improving cell performance via electrochemical and impedance techniques.

Acknowledsement - We gratefully acknowledge the technical interactions with our METC COR, William C. Smith. The period of performance for this program is $4 / 16 / 93$ through $4 / 15 / 98$. 